ARGONNE NATIONAL LABORATORY

9700 South Cass Avenue, Argonne, Illinois 60439

ANL/EES-TM- -312

ANL/EES-TM-312

DE87 013112

QUALITY ASSURANCE PROGRAM

ARGONNE PEER REVIEW ACTIVITIES FOR THE SALT HOST-ROCK PORTION OF THE CIVILIAN RADIOACTIVE WASTE MANAGEMENT PROGRAM

Controlled Copy Number:

Issued to:

Organization:

Prepared by:

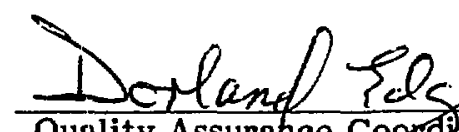

Quality Assuraqce Coad hator

D. E. Edgar

$\frac{8 / 12 / 86}{\text { Date }}$

Reviewed by: Tichando. Aoctor

EES Quality Assurance Representative R. D. Doctor
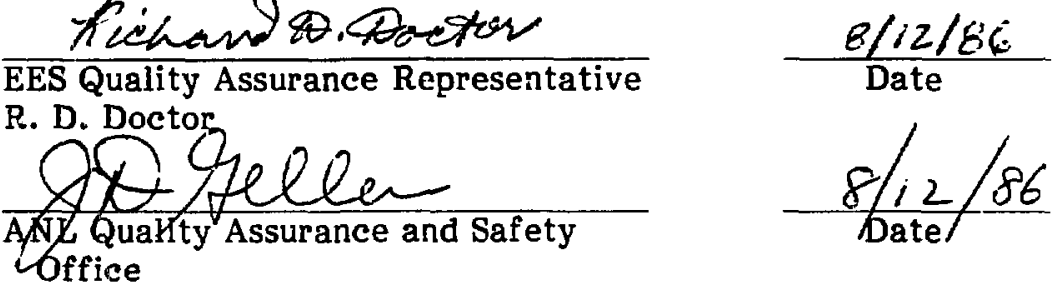

J. D. Geller

Approved by: W. Hamsion

Program Manager

W. Harrison 
Argonne National Laboratory, with facilitics in the states of Illinois and Idaho, is owned by the United States government, and operated by The University of Chicago under the provisions of a contract with the Department of Energy.

\section{DISCLAIMER}

This report was prepared as an account of work sponsored by an agency of the United States Governinent. Neither the United States Government nor any agency thereof, nor any of their employees, makes any warranty, express or implied, or assumes any legal liability or responsibility for the accuracy, completeness, or usefulness of any information, apparatus, product, or process disclosed, or represents that its use would not infringe privately owned rights. Reference herein to any specific commercial product, process, or service by trade name, trademark, manufacturer, or otherwise, does not necessarily constitute or imply its endorsement, recommendation, or favoring by the United States Government or any agency thereof. The views and opinions of authors expressed herein do not necessarily state or reflect those of the United States Government or any agency thereof. 
1 Organization

2 Quality Assurance Program

3 Design Control

$8 / 12 / 86$

4 Procurement Document Control

$8 / 12 / 86$

$5 \quad$ Instructions, Procedures, and Drawings

6 Document Control

$7 \quad$ Control of Purchased Items and Services

$8 / 12 / 86$

8 Identification and Control of Items

9 Control of Processes

10 Inspection

11 Test Control

12 Control of Measuring and Test Equipment

13 Handling, Storage, and Shipping

14 Inspection, Test, and Operating Status 
$17 \quad$ Quality Assurance Records

$18 \quad$ Audits

19 Deliverable Data and Reporting

Requirements
0

0

0

$8 / 12 / 86$

APPENDIX A: Correspondence between SRPO Quality Assurance Specification and ANL Quality Assurance Program

APPENDIX B: QAP-1, Design Control Procedures

$8 / 12 / 86$

APPENDIX C: QAP-2, Document Control Procedures

0

$8 / 12 / 86$

APPENDIX D: QAP-3, Inspection Procedures

$8 / 12 / 86$

APPENDIX E: QAP-4, Control of Nonconforming Items and Corrective Action Procedures

APPENDIX F: QAP-5, Quality Assurance Records Procedures

APPENDIX G: Deliverable Data and Reporting Requirements 
ARGONNE PEER REVIEW ACTIVITIES FOR THE SALT HOST-ROCK PORTION OF THE CIVILLAN RADIOACTIVE WASTE MANAGEMENT PROGRAM

FORE YORD

Project No.: 23562

Page: 1 of 4

Issued: $8 / 12 / 86$

Revision: 0

\section{BACKGROUND}

The Office of Civilian Radioactive Waste Management (OCRWM) of the U.S. Department of Energy (DOE) was established under Title III, Section 304, of the Nuclear Waste Policy Act (NWPA) of 1982 (Public Law 97-425). It is responsible for administering all provisions of NWPA. The Salt Repository Project Office (SRPO) of DOE, located in Columbus, Ohio, is responsible for administering that portion of the OCRWM program that pertains to the salt host-rock option for isolation of high-level radioactive waste. This responsibility requires ongoing research and technical efforts in many different fields of science and engineering.

Because of the diversity of work and the rigorous timetable for establishment of an operational repository required by NWPA, many of the detailed technical and programmatic tasks for the salt option are being performed through Battelle Memorial institute's Office of Nuclear Waste Isolation (ONWI) and other DOE contractors, under the supervision of SRPO. The Energy and Environmental Systems Division of Argonne National Laboratory (ANL) provides SRPO with multidisciplinary peer reviews of selected documents submitted to DOE by ONWI and other contractors to satisfy major milestones established by th: Salt Repository Project Office.

Th: primary purpose of ANL's multidisciplinary peer review task is to evaluate the adequacy and credibility of major contractor documents, to suggest revisions that appear to be needed, and to propose conditions for DOE acceptance. These peer reviews are conducted by multidisciplinary groups of independent experts in pertinent disciplines to assure DOE that the assumptions, methods, data, interpretations, and conclusions of the work performed or proposed are of superior quality in light of present scientific knowledge and current technology and that the work is responsive to all relevant regulatory concerns.

\section{ANL PROJECT NUMBER}

The peer review task is funded by SRPO under ANL project number 23562 . 
FOREWORD

Project No.: 23562

Page: 2 of 4

Issued: $8 / 12 / 86$

Revision: 0

\section{PURPOSE}

The purpose of this Quality Assurance (QA) Program is to set forth the methods, controls, and procedures used to ensure that the results of ANL's peer review activities are consistently of the highest quality and responsive to SRPO's needs and directives. Furthermore, implementation of the QA procedures described herein establishes an operational framework so that task activities are traceable and the activities and decisions that influence the overall quality of the peer review process and results are fully documented.

\section{RELATIONSHIP TO OTHER QA PROGRAMS, PROCEDURES, AND REQUIREMENTS}

This QA Program has been prepared using several documents as guidance. As stated in DOE Order 5700.6A of August 13,1981, DOE policy is that national consensus QA standards are to be applied to its programs if suitable ones are available. In this regard, Title 10, Part 50, of the Code of Federal Regulations (10 CFR 50) ${ }^{1}$ states that ANSI/ASME NQA-1 ${ }^{2-4}$ is the preferred standard for meeting the QA requirements for nuclear faciiities. Accordingly, on August 23, 1982, the Chicago Operations Office (CH) of DOE issued Order CH5700.6A, which establishes a conforming poliey for all $\mathrm{CH}$ programs and elements. Both SRPO and ANL are administratively responsible to $\mathrm{CH}$, and

${ }^{1}$ Quaitity Assurance Criteria for Nuclear Power Plants and Fuel Reprocessing Plants, Code of Federal Regulations, Title 10, Part 50 (10 CFR 50), App. B (Jan. 1, 1985).

${ }^{2}$ Quality Assurance Program Requirements for Nuclear Facilities, ANSI/ASME NQA-11983 Edition, American Society of Mechanical Engineers, New York (July 1, 1983).

3 Addenda to ANSI/ASME NQA-1-1983 Edition, ANSI/ASME NQA-1a-1983, American Society of Mechanical Engineers, New York (Dec. 31, 1983).

${ }^{4}$ Addenda to ANSI/ASME NQA-1-1983 Edition, ANSI/ASME NQA-1b-1984, American Society of Mechanical Engineers, New York (March 15, 1985). 


\section{ARGONNE PEER REVIEW ACTIVITIES FOR THE SALT HOST-ROCK PORTION OF THE CIVILIAN RADIOACTIVE WASTE MANAGEMENT PROGRAM}

FOREWORD

$\begin{aligned} \text { Project No.: } & 23562 \\ \text { Page: } & 3 \text { of } 4 \\ \text { Issued: } & 8 / 12 / 86 \\ \text { Revision: } & 0\end{aligned}$

both have developed and implemented QA programs ${ }^{5-7}$ in accordance with Order CH5700.6A. As a consequence, the requirements of ANSL/ASME NQA-1 are addressed by the stated QA policies of both SRPO and ANL.

Because the peer review task is being performed by ANL, task activities and procedures should conform to the ANL QA Program, while simultaneously meeting the QA requirements of SRPO. On Sept. 11, 1985, SRPO issued a QA specification for the ANL peer review task ${ }^{8}$ that presents SRPO requirements for documenting, implementing, and maintaining an adequate QA program for the peer review effort. These requirements are compatible with both the SRPO and ANL QA programs; therefore, this specification provided primary input and guidance for the preparation of this QA Program for the ANL peer review task.

\section{DOCUMENT ORGANIZATION}

Sections 1-19 constitute the QA Plan: Secs. 1-18 correspond to the 18 basic QA requirements presented in ANSI/ASME NQA-1, and Sec. 19 presents information on the requirements for deliverables and reporting for the project, as specified by SRPO. Because of the type of work performed for the peer review task, some of the basic requirements of NQA-1 are not applicable. This situation is noted in the sections corresponding to such requirements. Otherwise, appropriate QA requirements in NQA-1

${ }^{5}$ ANL Quality Assurance Policy and Procedures Manual, Argonne National Laboratory (most recently revised in July 31,1985 ).

${ }^{6}$ Quality Assurance Plan, U.S. Department of Energy, Salt Repository Project Office, Columbus, Ohio (Dec. 4, 1985).

${ }^{7}$ Quality Assurance Administrative Procedures, U.S. Department of Energy, Salt Repository Project Office, Columbus, Ohio (in preparation).

${ }^{8}$ Quality Assurance Specification for Argonne National Laboratory: Multidisciplinary Peer Reviews of DOE-Contractor Documents for Salt Host-Rock Portion of CRWM Program, U.S. Department of Energy, Salt Repository Project Office, Columbus, Ohio, unpublished document (Sept. 11, 1985). 
FOREWORD

Project No.: 23562

Page: 4 of 4

Issued: $8 / 12 / 86$

Revision: 0

and in the QA specification supplied by SRPO are presented, along with responsibilities and activities for meeting those requirements.

The QA Program also includes seven appendixes. The correspondence between specific elements of the QA specification provided by SRPO and the sections of the QA Plan is detailed in App. A. Appendixes B-F present the detailed QA procedures developed for implementing the project QA requirements set forth in the QA Plan, and App. $G$ contains information on the requirements for deliverables and reporting for the project. 
ARGONNE PEER REVIEW ACTIVITIES FOR THE SALT HOST-ROCK PORTION OF THE CIVILIAN RADIOACTIVE WASTE MANAGEMENT PROGRAM

\section{SECTION 1}

Organization 
ARGONNE PEER REVIEW ACTIVTTIES FOR THE SALT HOST-ROCK PORTION

OF THE CIVILIAN RADIOACTIVE WASTE MANAGEMENT PROGRAM

1 ORGANIZATION

Project No.: 23562

Page: 1 of 12

Issued: $8 / 12 / 86$

Revision: 0

\subsection{PURPOSE}

Section 1 of the Argonne National Laboratory (ANL) Quality Assurance (QA) Plan for the peer review task documents and describes the organizational structure, functional responsibilities, levels of authority, and lines of communication for activities affecting the quality of the peer review process and products.

\subsection{QA REQUIREMENTS}

Argonne National Laboratory shall deseribe and document in the QA Plan the organizational structure, functional responsibilities, levels of authority, and lines of communication for activities affecting the quality of work performed for the peer review task. The descriptions shall include an organization chart that clearly identifies ANL's internal and external organizational elements that function within the requirements of the QA Program, along with their lines of responsibility.

\subsection{LINE-MANAGEMENT ORGANIZATION}

The peer review task is a project within ANL's Energy and Environmental Systems (EES) Division, one of approximately 20 divisions at the Laboratory. The EES Division is organized into several administrative units based on disciplinary and programmatic criteria. As shown in Fig. 1.1, the peer review task is under the direct supervision of the Associate Division Director for Geoscience and Engineering (G\&E), who reports to the EES Division Director through a deputy division director.

Research and development projects and programs at ANL are organized administratively into the following principal areas: physical research; engineering research; and energy, environmental, and biological research. The activities within each of these research areas are the responsibility of an Associate Laboratory Director (ALD), who reports directly to the Laboratory Director. The EES Division is one of three scientific divisions and several multidisciplinary research programs under the direction of the ALD for Energy, Environmental, and Biological Research. 


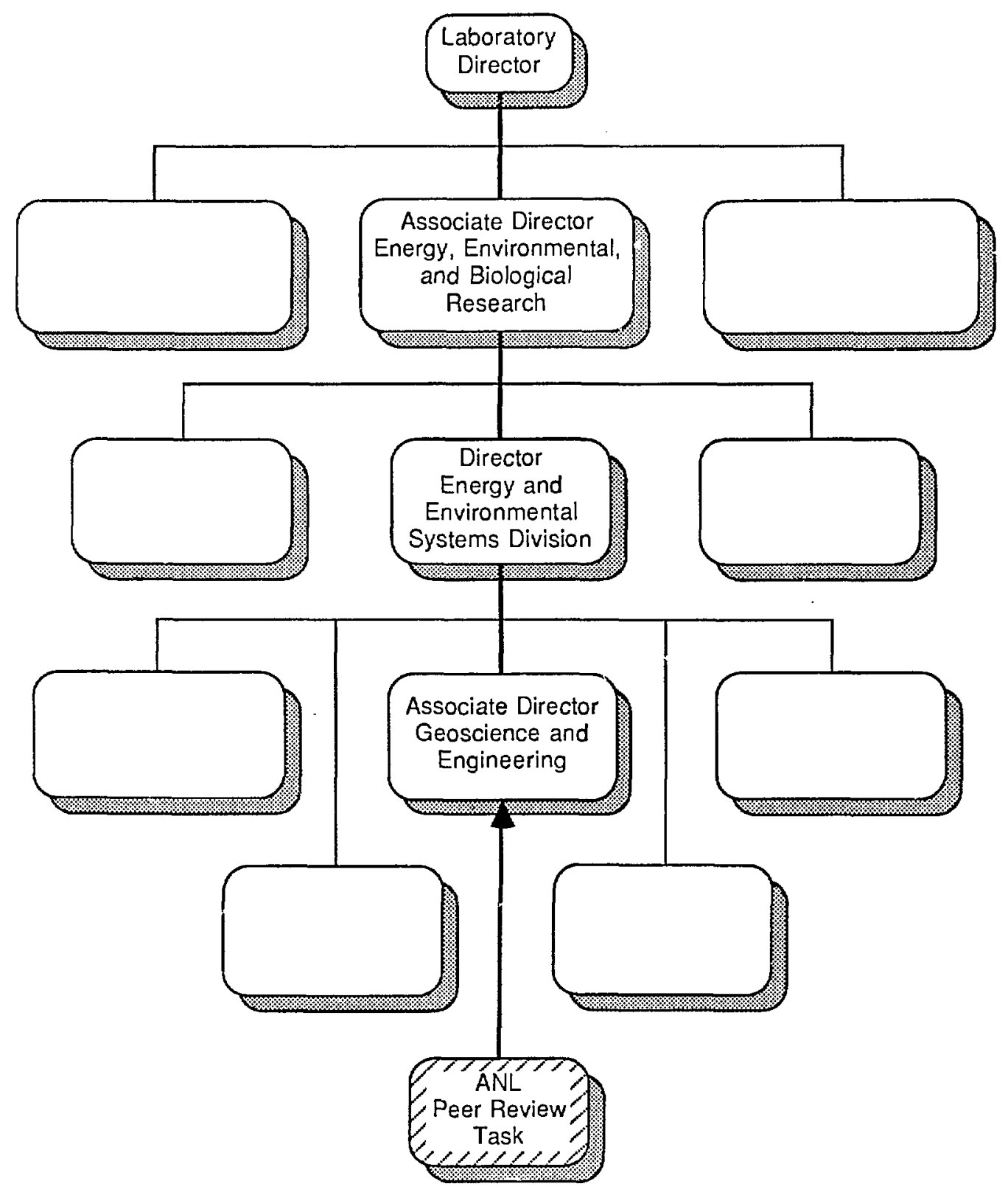

FIGURE 1.1 Line-Management Organization Chart for the ANL Peer Review Task 
ARGONNE PEER REVIEW ACTIVITIES FOR THE SALT HOST-ROCE PORTION

OF THE CIVILIAN RACIOACTIVE WASTE MANAGEMENT PROGRAM

1 ORGANIZATION

Project No:: 23562

Page: 3 of 12

Issued: $8 / 12 / 86$

Revision: 0

\subsection{ANL QA PROGRAM ORGANIZATION AND RESPONSIBILITIES}

The QA program organization for ANL is illustrated in Fig. 1.2 and discussed in detail in the ANL Quality Assurance Policy and Procedures Manual. Each major organizational unit at ANL has a designated and trained QA representative (QAR) responsible for providing $Q A$ guidance and assistance to managers and personnel within the respective ANL unit. In this capacity, the QAR is the primary pcint of contact for QA matters for each ANL organizational unit. Thus, the role of the QARs is fundamental to QA activities and reflects the decentralized nature of ANL's QA Program.

Figure 1.2 also shows two general types of interaction and lines of reporting within the ANL QA organization. Solid lines indicate direct reporting and administrative responsibilities through the line-management organization, whereas dotted lines reflect guidance, assistance, and coordination activities, and reporting on QA matters. Individual QA Rs interact with and receive assistance, guidance, and training from ANL's Quality Assurance and Safety Office (QASO). Although each QAR is administratively responsible to the management of his or her respective division, each QAR also reports to QASO on QA matters related to projects within the QAR's division.

Within ANL's QA Program, QASO provides centralized QA overview, review, audit, training, supplier system evaluation, and assistance to all ANL divisions, programs, and projects. Furthermore, QASO trains and tests the QARs designated by individual ANL divisions before their certification. The duties of a QAR include providing division personnel with assistance and guidance in preparing and implementing QA system descriptions, plans, plan revisions, and procedures; ensuring that each QA system, plan, revision, or procedure is reviewed and approved by appropriate members of the ANL QA program; assisting each project or program manager in establishing document control and maintaining QA record control; interacting with QASO in matters of QA policy to ensure division QA activities are in compliance with ANL QA policies; and participating in other QA activities as described in the ANL QA manual. 


\section{QUALITY ASSURANCE PROGRAM \\ ARGONNE PEER REVIEW ACTIVITIES FOR THE SALT HOST-ROCK PORTION OF THE CIVILIAN RADIOACTIVE WASTE MANAGEMENT PROGRAM}

1 ORGANIZATIGN

Project No.: 23562

Page: 4 of 12

Issued: $8 / 12 / 86$

Revision: 0

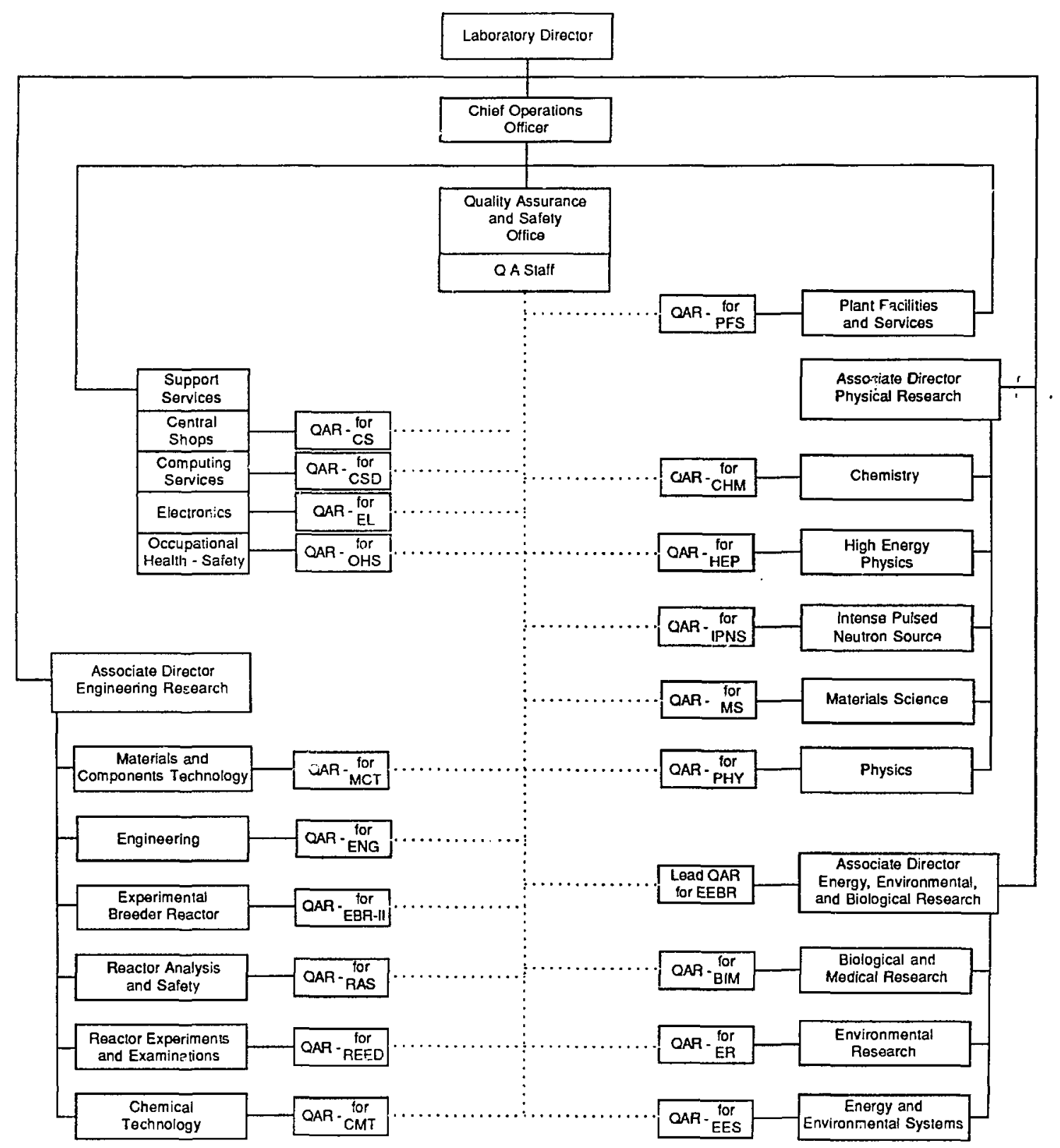


ARGONNE PEER REVIEW ACTIVITIES FOR THE SALT HOST-ROCK PORTION

OF THE CIVILIAN RADIOACTIVE WASTE MANAGEMENT PROGRAM

1 ORGANIZATION

Project No.: 23562

Page: 5 of 12

Issued: $8 / 12 / 86$

Revision: 0

Each QAR has the authority to identify quality problem: : initiate or recommend solutions to quality problems, and to verify implementation of corrective actions. This autiority is extended to all projects and programs with QA componen ts within the QAR's respective division. In this capacity, the QAR reports on the division's QA Program to ANL's QASO. This line of reporting, which is independent of the division line-management structure, provides each QAR with access to upper-levei division management. Such independence permits effective resolution of quality problems at the project and program level.

\subsection{EES DIVISION QA ORGANIZATION}

As shown in Fig. 1.1, EES is divided administratively into several units. All units are represented on the EES QA committee, which consists of these representatives and additional individuals from division management. The committee, which is chaired by the QAR for the division, functions as an oversight and assistance group for QA activities for programs and projects within the division. As indicated in Fig. 1.3, the EES QA committee receives direction, guidance, and assistance from ANL's QASO through the EES QAR. In turn, committee members provide QA guidance and assistance to staff in their respective units within EES. Because the peer review task is performed in the G\&E Group of EES, the QA committee member from G\&E is primarily responsible for formulating, implementing, and monitoring QA procedures and activities for this task. In this capacity, the EES QA committee member from G\&E also serves as QA Coordinator for the Peer Review Panel.

In addition to the QA organization illustrated in Fig. 1.3, QASO has assigned a Quality Engineer (QE) to EES. The $Q E$, who has an independent quality function, is responsible for ensuring that appropriate QA plans are established for projects with such needs and for overviewing activities affecting quality. The QE has sufficient authority, access to work areas, and organizational freedom to (1) identify quality problems; (2) initiate, recommend, or provide solutions to quality problems through designated 


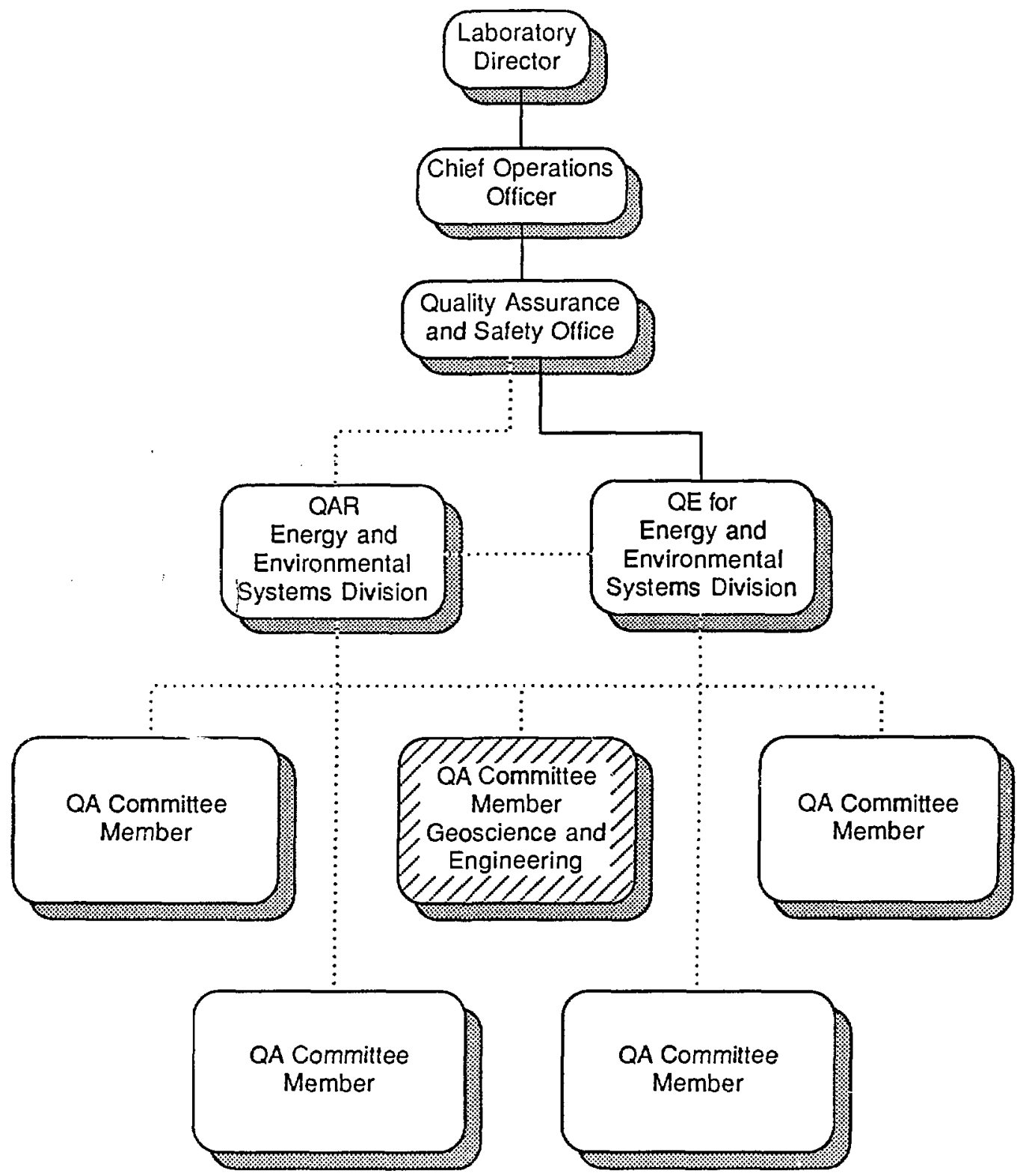


channels; (3) verify implementation of solutions; and (4) assure that further processing, delivery, installation, or use is controlled until proper disposition of a nonconformance, deficiency, or unsatisfactory condition has occurred. The QE has direct access to upperlevel ANL management through the head of QASO. In other words, the necessary authority and organizational freedom are provided, including sufficient independence from cost and schedule considerations.

For the peer review task, the $\mathrm{QE}$ will be directly available to assist and advise the QA Coordinator on QA matters as well as performing those functions stated in the previous paragraph on a regular basis. In this role, the $\mathrm{QE}$ will be able to relieve the EES QAR and project QA Coordinator of the organizational pressures that may be associated with resolving quality problems when such resolution requires the involvement of upperlevel ANL management.

\subsection{ANL PEER REVIEW PANEL ORGANIZATION AND RESPONSIBILITIES}

The Peer Review Panel comprises the core peer review group and auxiliary peer review panelists (Fig. 1.4). All core group panelists are staff members of the G\&E Group of EES, whereas the auxiliary panelists are individuals from other groups within EES or other ANL divisions, or from other national laboratories, companies, or academic institutions. A few of the off-site panelists are self-employed. Panelists are selected primarily on the basis of their research experience and expertise. Figure 1.4 suggests that auxiliary panelists provide expertise in six areas; in actuality, experts from numerous scientific and technical disciplines are available to complement and supplement the expertise of core group panelists on an as-needed basis.

\subsubsection{Peer Review Panel Chairman}

As project manager of the peer review task, the Peer Review Panel Chairman is responsible for all task activities, including establishing, administering, and enforcing QA 


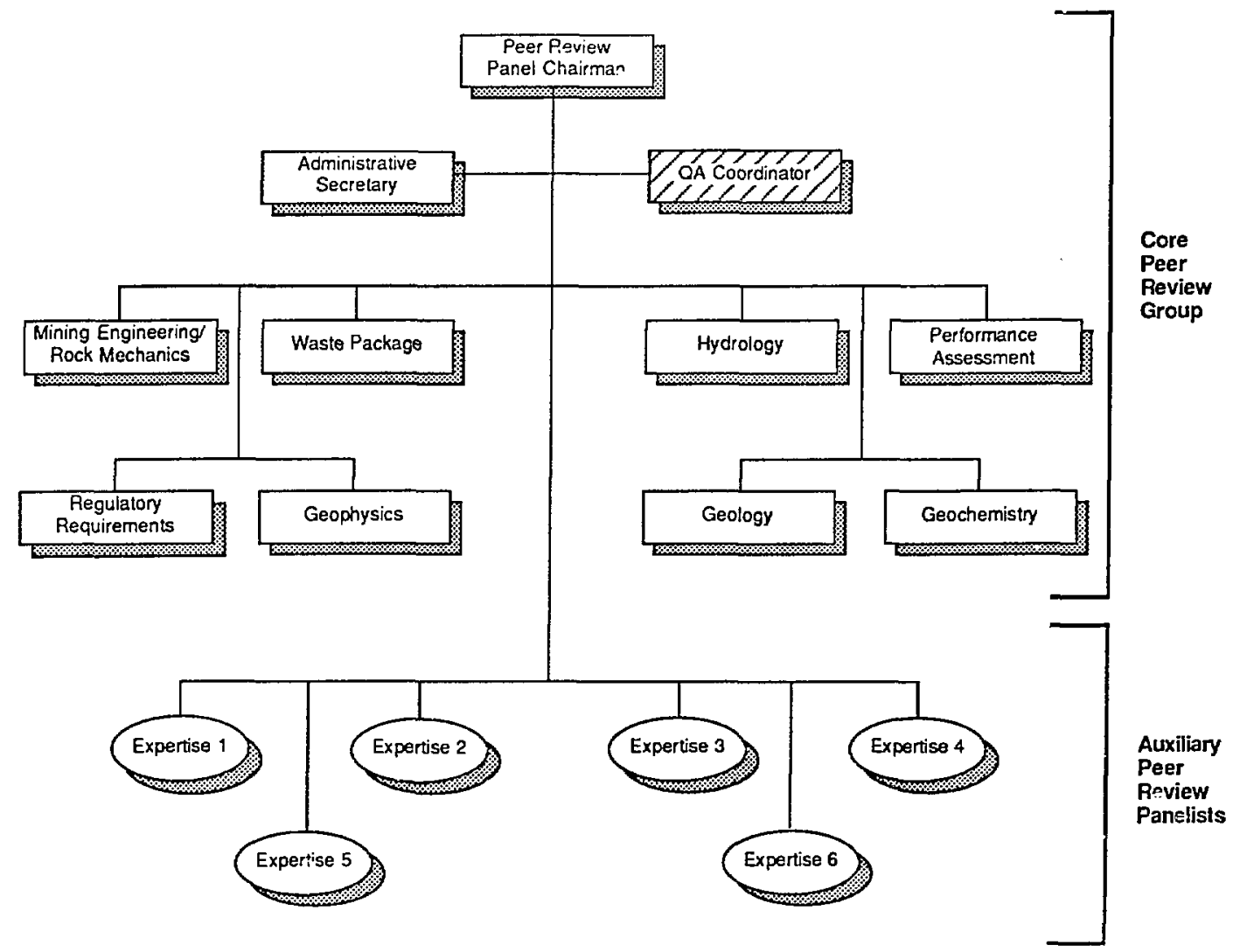

FIGURE 1.4 Organization and Capabilities of the ANL Peer Review Panel

policies and procedures. The responsibilities and duties of the chairman also include the following:

- Identification and selection, with SRPO concurrence, of core peer review group staff.

- Identification and selection, with SRPO concurrence, of auxiliary on-site and off-site panelists. 
- Interaction with SRPO's manager, deputy manager, and appropriate SRPO line managers on all task activities.

- Coordination and administration of all task activities.

The Peer Review Panel Chairman has delegated to the Project QA Coordinator the responsibility for developing the QA Program (plan and implementing procedures) for the peer review task and the authority to verify its implementation and effectiveness. The responsibility for implementing the QA Program has been delegated to all members of the core peer review group who perform quality-related activities. As project manager, the Peer Review Panel Chairman ensures that the peer review task is in compliance with all QA requirements as contained in this QA Program.

\subsubsection{Administrative Secretary}

The Administrative Secretary for the Peer Review Panel processes all formal correspondence concerning task activities and is responsible for maintaining all project records and files, including documenting and maintaining records of all task activities having a direct bearing on the quality and content of review reports. The person in this pcsition must be familiar with and capable of correct implementation of appropriate and approved QA procedures. Responsible for organizing, filing, and retrieving all QA records associated with the peer review task, the Administrative Secretary interacts directly with the Peer Review Panel Chairman, QA Coordinator, and core peer review staff members.

\subsubsection{Project QA Coordinator}

The QA committee member for the G\&E Group of EES (Fig. 1.3) is also the QA Coordinator for the peer review task (Fig. 1.4). This individual reports to the Peer Review Panel Chairman and is responsible for developing and administering the QA Program for peer review task activities. This organizational relationship provides the 


\section{QUALITY ASSURANCE PROGRAM \\ ARGONNE PEER REVIEW ACTIVITIES FOR THE SALT HOST-ROCK PORTION OF THE CIVILLAN RADIOACTIVE WASTE MANAGEMENT PROGRAM}

1 ORGANIZATION

$\begin{aligned} \text { Project No.: } & 23562 \\ \text { Page: } & 10 \text { of } 12 \\ \text { Issued: } & 8 / 12 / 86 \\ \text { Revision: } & 0\end{aligned}$

QA Coordinator with sufficient authority, organizational freedom, and independence from cost and schedule demands and influences to effectively administer the QA Program.

The QA Coordinator receives guidance and assistance from and shall interact directly with the EES Division QAR, as well as with the QE from QASO, to ensure that peer review QA activities and procedures are appropriate and consistently applied and that they are consistent with ANL and EES policies and procedures. The QA Coordinator is also responsible for training and indoctrination of peer review task staff to ensure familiarity with the QA Program. The QA Coordinator also verifies that individual core group members follow! appropriate QA procedures while performing task activities.

\subsubsection{Core Peer Review Group Staff}

As indicated in Fig. 1.4, staff members of the core peer review group provide expertise in eight scientific, technical, and programmatic areas. The individuals providing this expertise participate in the review of specific documents on an as-needed basis, depending on the content of the document being reviewed. More specifically, the Peer Review Panel Chairman selects individual core group staff members to serve on a particular review panel based on the chairman's preliminary examination of the document to be reviewed, as well as on any guidance received from SRPO with respect to key areas of concern or particular points to consider during the review.

The primary responsibilities of the core group staff are to evaluate from a technical and programmatic viewpoint documents submitted by SRPO for peer review and to provide written comments, as requested by the Peer Review Panel Chairman. To do this effectively, each staff member must remain familiar with the research activities and findings within his or her respective area of expertise and must understand how these research results relate to the Civilian Radioactive Waste Management (CRWM) program in general and to Salt Repository Project (SRP) activities in particular. In addition, during the course of a review, an individual core staff member may be required to 
interact with auxiliary panelists with similar or related expertise on technical or programmatic points.

Each member of the core peer review group shall be familiar with the QA Program for the peer review task. Each core staff member shall ensure that activities related to the task are concucted in accordance with established QA procedures. To do this, staff members must understand all current QA procedures for the peer review task, but particularly those procedures that relate directly to their roles in a given review or that are associated with task activities related to or are in support of the review process.

\subsubsection{Auxiliary Peer Review Panelists}

Peer review panelists other than those in the core peer review group are ANL staff members (on-site panelists) or individuals who are self-employed or employed by other national laboratories, companies, or academic institutions (off-site panelists). All of these auxiliary panelists are available to participate in peer review activities on an asneeded basis. With the exception of individuals from other national laboratories, all of site personnel are under contract to ANL and must be available to respond in a timely manner to a request for their participation in a given review activity.

Auxiliary panelists are initially selected based on their areas of expertise and on their recognized research capabilities and experience. Specific individuals are selected to serve on a given Peer Review Panel by the Peer Review Panel Chairman, with input from core group members. Consideration is given to the content of the document to be reviewed, to any specific requirements or areas of concern indicated by SRPO, and to the particular areas of expertise required to perform the review.

Because peer review task QA procedures are administered within the ANL core group, auxiliary panelists are not required to be familiar with all of the QA activities and requirements as presented in this QA Program. However, they are responsible for keeping current with research activities and results in their respective areas of expertise and for maintaining a capability to provide a high-quality review on short notice. 
An individual selected to serve as an auxiliary panelist for a specific review receives detailed instructions from the Peer Review Panel Chairman and the designated Review Session Chairman as to what is to be covered, as well as any specific guidance or information provided to the Peer Review Panel Chairman by SRPO. Such instructions are forwarded simultaneously with the material to be reviewed. Copies of all instructions are maintained as part of the project QA records. The Peer Review Panel Chairman, the Review Session Chairman (see App. B, Sec. B.4.2), or designated members of the core group are responsible for determining whether the review performed by an auxiliary panelist, as evidenced by the written material provided, is appropriate and adequate in terms of the instructions provided by ANL.

All QA records relating to the participation of an auxiliary panelist in any given review shall be maintained at $A N L$ by the Administrative Secretary, following the requirements prescribed in Sec. 17 and the procedures presented in App. F.

\subsection{REFERENCES}

ANL Quality Assurance Policy and Procedures Manual, Argonne National Laboratory (most recently revised on July 31,1985 ).

Basic Requirements: 1. Organization, in Quality Assurance Program Requirements for Nuclear Facilities, ANSI/ASME NQA-1-1983 Edition, American Society of Mechanical Engineers, New York, p. 2 (July 1, 1983).

Quality Assurance Specification for Argonne National Laboratory: Multidisciplinary Peer Reviews of DOE-Contractor Documents for Salt Host-Rock Portion of CRWM Program, U.S. Department of Energy, Salt Repository Project Office, Columbus, Ohio, unpublished document (Sept. 11, 1985). 
QUALITY ASSURANCE PROGRAM

ARGONNE PEER REVIEW ACTIVITIES FOR THE SALT HOST-ROCK PORTION OF THE CIVILIAN RADIOACTIVE WASTE MANAGEMENT PROGRAM

SECTION 2

Quality Assurance Program 
ARGONNE PEER REVIEW ACTIVITIES FOR THE SALT HOST-ROCK PORTION OF THE CIVILIAN RADIOACTIVE WASTE MANAGEMENT PROGRAM

2 QUALITY ASSURANCE PROGRAM

Project No.: $\mathbf{2 3 5 6 2}$

Page: 1 of 7

Issued: $8 / 12 / 86$

Revision: 0

\subsection{PURPOSE}

Section 2 describes the basis for the QA Program for the peer review task.

\subsection{QA REQUIREMENTS}

ANL shall develop, document, and implement a QA program that complies with the SRPO specification. (Controlled copies of the program shall be submitted to SRPO before use or after revision.) The commitment to and implementation of the program shall be described in a QA plan, which shall be project-specific and include, but shall not necessarily be limited to, the following:

- ANL shall describe why the plan is necessary and what its objectives are.

- ANL shall briefly describe what the plan is, what it encompasses, and how it relates to quality-related requirements applicable to the work activities.

- ANL shall describe the organizational structure, clarily the responsibilities of individuals in that structure, and indicate the interfaces between QA functions, managers, and technical organizations, including subcontractor organizations. ANL shall also describe how quality-related activities are executed, including subcontracted activities, and shall specify implementing $Q A$ and technical procedures (existing and proposed).

- ANL shall provide complete citations for all cited references, which might include regulations, standards, specifications, QA manuals, or subcontractor QA programs or plans. 
- ANL shall supplement the QA Plan by referring to work or test plans, technical and QA procedures, and other documentation prepared or planned for accomplishing project activities.

- ANL shall identify and list all QA and technical procedures (existing or proposed) to assure that each criterion supplied by SRPO (Sec. 2.9) and in the QA Plan will be met.

- ANL shall describe and document how managers above and outside the QA organization regularly assess the scope, status, adequacy, and effectiveness of the QA Program.

- ANL shall describe and document measures that assure that persons performing quality-related activities and those verifying activities affecting quality have been indoctrinated and trained, and that they are qualified for these tasks. Appropriate managers shall monitor the performance of individuals involved in activities affecting quality and shall determine the need for retraining or replacement.

- ANL shall maintain records concerning the qualifications of QA personnel and their indoctrination and training.

\subsection{GEMERAL}

This QA Program describes and documents the organizational structures, responsibilities, activities, and procedures associated with the QA requirements for the peer review task. The plan is in accordance with the pertinent requirements of NQA-1 and the QA specification provided by SRPO (Sec. 2.9). However, because of the nature of the peer review task, not all of the basic and supplementary requirements of NQA-1 directly apply to project activities and products (Table 2.1). For applicable NQA-1 
QUALITY ASSURANCE PROGRAM

ARGONNE PEER REVIEF ACTIVTTIES FOR THE SALT HOST-ROCE PORTION OF THE CIVILIAN RADIOACTIVE WASTE MANAGEMENT PROGRAM 
requirements, the means of satisfying the requirements are presented; where appropriate, detailed implementation procedures for specific work activities are pruvided.

This QA Program has been prepared to establish and implement the methods, procedures, and controls necessary to ensure that the results of the ANL peer review task are consistently of high quality and are responsive to SRPO's directives and needs. The procedures described in this program establish an operational framework for key work activities so that those activities are traceable and that the activities and decisions that influence the quality of the peer review process and results are fully documented.

Implementation of the concepts, intent, methods, and procedures contained or referenced in this QA Program will enable attainment of the two primary quality-related objectives for the peer review task. The first objective -- achievement of quality -- is the conduct of quality-related activities in accordance with applicable technical requirements and good work practices. The second objective -- verification of quality -is the independent determination that quality-related activities are acsomplished in an adequate manner and in accordance with applicable specified technical and administrative requirements.

\subsection{ORGANIZATION AND RESPONSIBILITIES}

Section 1 of this QA Program describes the line-management relationships among QA organizational elements and their general responsibilities with respect to the peer review task.

\subsection{INDOCTRINATION AND TRAINING}

\subsubsection{General}

As discussed in Sec. 1.4, ANL's QASO trains and tests all QARs designated by individual ANL divisions prior to their certification by QASO. Thus, as discussed in Sec. 1.5, the QAR for the EES Division is the principal source of information on QA matters 
for EES staff, including those involved in the peer review task. The EES QAR is responsible for informing all members of the EES QA committee (Fig. 1.3) of current ANL and EES QA policies and procedures and for providing guidance and assistance in preparing QA plans and procedures for individual projects and programs within EES. These tasks are accomplished through personal consultation with management and staff members, through preparation and distribution of written materials, and through periodic meetings of the committee held at the discretion of the EES QAR. Each member of the EES QA committee, in turn, provides information, guidance, and assistance to staff members within his or her respective group.

\subsubsection{Peer Review Group}

As noted in Sec. 1.5, managers of administrative units within the EES Division designate representatives tc serve on the EES QA committee. That individual is selected because he or she is interested in working within the QA organization, has the time available to perform these duties, and is technically qualified and familiar with the technical and programmatic aspects of the projects and programs conducted within the group.

The EES QA committee member for the G\&E Group is the QA Coordinator for the peer review task. This individual receives training on ANL QA policy and procedures, as well as on general QA matters, from QASO. All training received by the QA Coordinator shall be fully documented, and these records shall be maintained in the project QA files.

The QA Coordinator is responsible for informing staff participating in the peer review task of current ANL and EES QA policies and procedures and for ensuring that core peer review group staff members are familiar with the QA Program as developed for the peer review project. Each member of the core group shall receive a controlled copy of the approved QA Program and any revisions. Each core group member shall become familiar with the program and seek clarification from the project QA Coordinator of any points of confusion. After becoming familiar with the QA Program, 


\section{QUALITY ASSURANCE PROGRAM \\ ARGONNE PEER REVIEW ACTIVITIES FOR THE SALT HOST-ROCK PORTION \\ OF THE CIVILLAN RADIOACTIVE WASTE MANAGEMENT PROGRAM}

2 QUALITY ASSURANCE PROGRAM

Project No.: 23562

Page: 6 of 7

Issued: $8 / 12 / 86$

Revision: 0

each member shall sign a verification statement indicating that he or she has studied the program and that he or she understands the content. These signed statements shall become part of the project QA records.

The QA Coordinator is responsible for the orientation of core peer review group personnel in QA matters for the peer review task. Several orientation sessions shall be scheduled and conducted by the QA Coordinator to ensure that all core group staff are familiar with and can appropriately implement the QA procedures developed for the peer review task. Announcements of orientation sessions shall be distributed to those required to attend and shall describe the subjects to be covered. Individuals attending the sessions shall sign a sheet to document their presence. Those unable to attend such meetings shall receive analogous orientation on an individual basis from the QA Coordinator. All pertinent facts regarding this initial series of orientation sessions, including date, location, subjects covered, and individuals receiving orientation, shall be documented for the project $Q A$ records.

After the initial series of orientation sessions, core group meetings shall be held periodically, on an as-needed basis, to discuss QA concerns for the peer review task and any ANL or EES QA matters affecting project activities. Such meetings shall be called at the discretion of the project QA Coordinator or at the suggestion of the EES QAR. Furthermore, the QA Coordinator shall provide core group members with written material, on an as-needed basis, that describes pertinent QA information resulting from meetings of the EES QA committee or from interactions between the G\&E QA committee member and the EES QAR. Records of meetings, correspondence or transmittals, or other formal actions having a bearing on the QA Program will be maintained in the project QA files.

\subsection{MANAGEMENT ASSESSMENT OF QA PROGRAM}

As project manager, the Peer Review Panel Chairman is responsible for periodicaliy assessing the adequacy and effectiveness of the implemented QA Program for the peer review task. He or she shall be fully informed of QA efforts and activities 
on an ongoing basis through periodic meetings with the project QA Coordinator and through routile examination of documentation of project QA actions and activities routed to the chairman. At least annually, the Chairman shall assess the adequacy and effectiveness of the implementation of the QA Program. The results of this assessment shall be documented and maintained in the project QA files. Any actions taken as a result of this assessment shall also be documented for the project $Q A$ files.

\subsection{RIGHT OF SRPO ACCESS}

Work performed by ANL or its subcontractors under the peer review task shall be accessible at reasonable times during normal working hours for the purposes of audit; surveillance, inspection, or visit by authorized representatives of SRPO.

\subsection{SRPO NOTIFICATION}

SRPO shall notify the ANL Peer Review Panel Chairman and QA Coordinator in writing of the intent to exercise its right of access and the purpose of such access. Such notification shall be received by the chairman and QA Coordinator at least 15 working days before the date access is desired.

\subsection{REFERENCES}

ANL Quality Assurance Policy and Procedures Manual, Argonne National Laboratory (most recently revised on July 31,1985 ).

Basic Requirements: 2. Quality Assurance Program, in Quality Assurance Program Requirements for Nuclear Facilities, ANSI/ASME NQA-1-1983 Edition, American Society of Mechanical Engineers, New York, p. 2 (July 1, 1983).

Quality Assurance Specification for Argonne National Laboratory: Multidisciplinary Peer Reviews of DOE-Contractor Documents for Salt Host-Rock Portion of CRWM Program, U.S. Department of Energy, Salt Repository Project Office, Columbus, Ohio, unpublished document (Sept. 11, 1985). 
QUALITY ASSURANCE PROGRAM

ARGONNE PEER REVIEW ACTIVTTIES FOR THE SALT HOST-ROCK PORTION OF THE CIVILIAN RADIOACTIVE WASTE MANAGEMENT PROGRAM

SECTION 3

Design Control 
ARGONNE PEER REVIEW ACTIVTIES FOR THE SALT HOST-ROCK PORTION

OF THE CIVILLAN RADIOACTIVE WASTE MANAGEMENT PROGRAM

3 DESIGN CONTROL

Project No.: 23562

Page: 1 of 6

Issued: $8 / 12 / 86$

Revision: 0

\subsection{PURPOSE}

Section 3 describes the planned and systematic actions necessary to assure that the activities and results of the ANL peer review task are of consistently high quality and responsive to SRPO's needs and directives.

\subsection{QA REQUIREMENTS}

The following QA requirements are contained in the referenced documents.

- ANL shall establish measures to verify that the peer reviews of technical documents submitted by SRPO are performed by competent individuals or groups and that the results of these reviews are adequately documented and approved. Written procedures shall identify the methods used to document, resolve, and approve the results of the peer review process.

- ANL shall define, as part of the peer review procedures, the reviewer selection process and the qualification criteria.

- ANL shall implement a tracking system for review results to assure that all review comments are identified and protected, from initial receipt through final reporting (publication), and stored subsequent to publication.

- ANL shall establish review criteria for each type of technical document subjected to peer review to assure that review results are adequate and traceable.

- If data or information outside the furnished review material is used to substantiate a comment or recommendation, ANL shall document 
the reference material or it shall be attached to the review comments.

- ANL shall issue a report for each peer review to assure that all comments and recommendations have been addressed and that the supporting rationale for decisions is documented. The results of peer reviews shall be reviewed and approved by the ANL Peer Review Panel Chairman.

- The final report shall state the purpose of the review and shall identify the document reviewed, the author(s) and the originating organization(s), the reviewers and their respective affiliations and disciplines, and the conclusions reached and recommendations made. Sources shall be provided for any data required to explain the technical basis for decisions or statements of alternative solutions to problems considered during the review. The final report shall also state whether the reviewed document is adequate and present any recommended changes.

- ANL shall attach a compilation of pertinent documents, correspondence, and references to the completed report.

- ANL shall transmit the completion report and supporting documents to the SRPO Project Manager within 45 days following receipt of the document to be reviewed. Should some documents require additional time for review, a completion date shall be recommended to and approved by the SRPO Project Manager. 
- ANL shall describe and document the QA organization's involvement in the peer review program.

\subsection{GENERAL}

The purpose of the ANL peer review task is to evaluate the adequacy and credibility of documents submitted by contractors and subcontractors to SRPO to satisfy major project milestones and to present the results of technical work. Review reports prepared by ANL and submitted to SRPO present the results of the peer review, including suggested revisions and proposed conditions for DOE/SRPO acceptance.

The participation of independent experts in pertinent scientific and technical disciplines assures DOE that the assumptions, methods, data, interpretations, and conclusions of the work performed or proposed are of acceptable quality in light of present scientific knowledge and current technology and that the reviewed document is responsive to relevant regulatory concerns.

Within the context of SRP activities, "design" refers to the specifications, drawings, design criteria, or performance requirements for the natural and engineered components of a repository system from conceptual through final design. Design information and activities refer to data collection, computer analysis, and other activities in support of design development and ver:fication.

Because peer review is integral to evaluation of the technical and scientific work (either planned or completed) broadly defined as design information and activities, the peer review process represents one element of design control procedures for SRPO. Furthermore, because the product of the peer review process is a report describing the results of a particular review, the procedures devised and implemented to ensure the quality of the review process and products may also be termed design control procedures. 


\subsection{IMPLEMENTATION PROCEDURES}

ANL has devised a standard procedure to ensure that the peer review process and associated review reports are consistently of high quality and that all activities having a direct bearing on the content of review reports are fully documented and traceable. Measures have been taken to ensure that reviews are performed by technically competent individuals and to track review results to ensure that all review comments are identified and protected from initial receipt through final disposition.

Figure 3.1 shows the main steps in the ANL peer review of documents for SRPO. Each step, along with additional important aspects of the peer review process, is described in App. B. The records generated by the review task to document the process and the implementation procedures associated with generation of the records and their storage and maintenance in the project QA files are described in Sec. 17 and App. F.

\subsection{LENGTH OF REVIEW CYCLE}

The time required to complete a review for SRPO will vary, depending on the document. The amount of time provided for a particular review shall be determined by the cognizant SRPO manager, with input from the ANL Peer Review Panel Chairman and with the concurrence of the SRPO Project Manager.

\subsection{FINAL PEER REVIEW REPORT}

For each peer review conducted by ANL, two draft versions of the peer review report shall precede final publication (Fig. 3.1 and App. B). Each published report shall satisfy the requirements given in Sec. 3.2. If unpublished or otherwise generally unavailable information or data are referenced in support of some aspect of the review, a copy of this material shall be supplied to SRPO with the initial draft. Published or otherwise readily accessible information or data shall not be routinely provided with the review report. All documentation of the review process, including pertinent correspondence, shall be maintained in the project QA files and transmitted to SRPO during annual records turnover. 

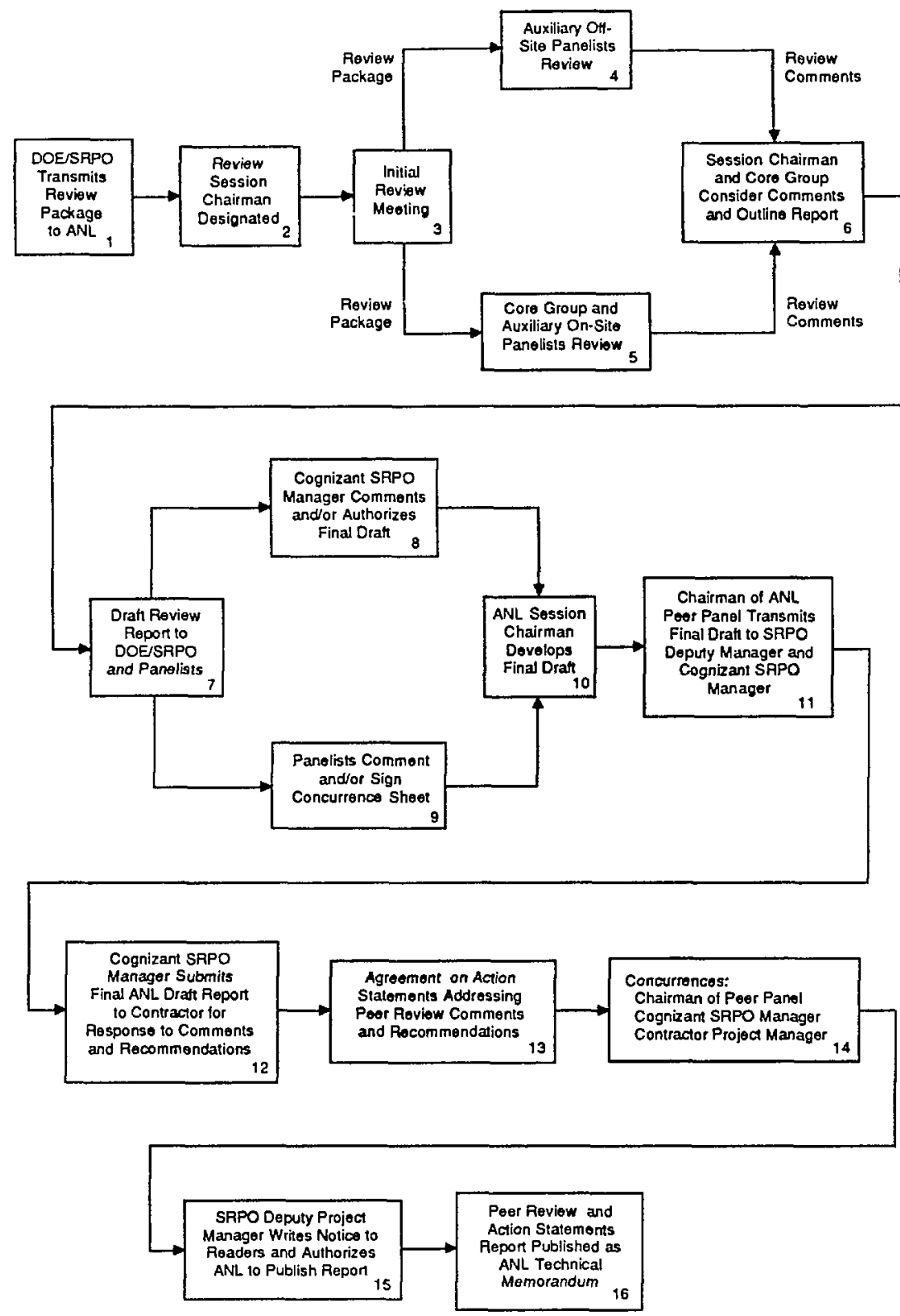

FIGURE 3.1 Main Steps in the ANL Peer Review Process 


\subsection{REFERENCES}

ANL Quality Assurance Policy and Procedures Manual, Argonne National Laboratory (most recently revised on July 31,1985 ).

Basic Requirements: 3. Design Control, in Quality Assurance Program Requirements for Nuclear Facilities, ANSI/ASME NQA-1-1983 Edition, American Society of Mechanical Engineers, New York, p. 2 (July 1, 1983).

Quality Assurance Specification for Argonne National Laboratory: Multidisciplinary Peer Reviews of DOE-Contractor Documents for Salt Host-Rock Portion of CRWM Program, U.S. Department of Energy, Salt Repository Project Office, Columbus, Ohio, unpublished document (Sept. 11, 1985). 
QUALITY ASSURANCE PROGRAM

ARGONNE PEER REVIEW ACTIVTIES THE FOR SALT HOST-ROCK PORTION OF THE CIVLLAN RADIOACTIVE WASTE MANAGEMENT PROGRAM

\section{SECTION 4}

Procurement Document Control 


\subsection{PURPOSE}

Section 4 describes the measures to ensure adequate quality in the procurement of items and services for the peer review task.

\subsection{QA REQUIREMENTS}

Applicable design bases or other requirements to ensure adequate quality shall be included or referenced in documents concerning the procurement of items and services. To the extent necessary, procurement documents shall require suppliers to have a QA program consistent with applicable requirements of ANSI/ASME NQA-1.

\subsection{APPLICABLLITY OF PROCUREMENT DOCUMENT CONTROL REQUIREMENTS}

Standardized and established ANL procurement procedures are used to obtain the services of contracted auxiliary peer review panelists; therefore, special procurement QA procedures are not required. However, the QA Coordinator shall review all purchase requisitions for the services of auxiliary peer review panelists to assure that appropriate QA provisions are included in the scope of work for these individuals. The QA Coordinator shall sign the purchase requisitions as evidence of this review and concurrence with the scope of work content.

\subsection{REFERENCES}

Basic Requirements: 4. Procurement Document Control, in Quality Assurance Program Requirements for Nuclear Facilities, ANSI/ASME NQA-1-1983 Edition, American Society of Mechanical Engineers, New York, p. 2 (July 1, 1983).

Procurement Procedure Manual, Argonne National Laboratory (most recently revised in March 1985).

Quality Assurance Specification for Argonne National Laboratory: Multidisciplinary Peer Reviews of DOE-Contractor Documents for Salt Host-Rock Portion of CRWM Program, U.S. Department of Energy, Salt Repository Project Office, Columbus, Ohio, unpublished document (Sept. 11, 1985). 
QUALITY ASSURANCE PROGRAM

ARGONNE PEER REVIEW ACTIVITIES FOR THE SALT HOST-ROCK PORTION OF THE CIVILIAN RADIOACTIVE WASTE MANAGEMENT PROGRAM

SECTION 5

Instructions, Procedures, and Drawings 
ARGONNE PEER REVIEW ACTIVITIES FOR THE SALT HOST-ROCK PORTION OF THE CIVILIAN RADIOACTIVE WASTE MANAGEMENT PROGRAM

5 INSTRUCTIONS, PROCEDURES, AND DRAWINGS

Project No.: 23562

Page: 1 of 3

Issued: $8 / 12 / 86$

Revision: 0

\subsection{PURPOSE}

Section 5 describes the general measures taken to ensure that activities affecting quality are prescribed by and performed in accordance with documented instructions, procedures, or drawings appropriate for the peer review task.

\subsection{QA REQUIREMENTS}

Activities affecting quality shall be prescribed by and performed in accordance with documented instructions, procedures, or drawings of a type appropriate to the circumstances. These documents shall include or reference appropriate acceptance criteria for determining that prescribed activities have been satisfactorily accomplished.

\subsection{QA INSTRUCTIONS AND PROCEDURES}

The basic QA instructions and procedures for conducting peer review activities are detailed in this QA Program. Indoctrination and training of peer review personnel in terms of these procedures and astociated QA matters are discussed in Sec. 2. If revisions or modifications of this program are required, substitute sections shall be prepared by the project QA Coordinator. Following review and approval, these revised sections shall be distributed to individuals possessing controlled copies of the program, in accordance with the document control procedures described in App. C.

Specific QA instructions or procedures required for a particular task activity shall be prepared by the project QA Coordinator and distributed to appropriate individuals in the peer review group. Copies of such instructions or procedures shall be maintained in the project $Q A$ files. The project $Q A$ Coordinator shall monitor peer review activities to ensure that pertinent $\mathrm{QA}$ instructions and procedures are followed. 


\subsection{RESPONSIBILITIES}

\subsubsection{Peer Review Panel Chairman}

As project manager, the Peer Review Panel Chairman has the primary responsibility for ensuring that activities affecting quality are planned and documented to satisfy the requirements of the QA Program. More specifically, the chairman is responsible for identifying the need for new technical procedures governing activities affecting quality or for modifying existing procedures. The project QA Coordinator, EES QAR, and QASO QE shall assist in such identifications as necessary. New or modified procedures and instructions shall be prepared by the chairman, with input from selected members of the core group. Such procedures and instructions may be in the form of memoranda or letters of transmittal.

\subsubsection{Project QA Coordinator}

The project QA Coordinator is responsible for developing QA instructions and procedures as necessary and for providing the training covering all QA-related procedures. New or revised QA procedures and instructions may be in the form of memoranda, letters, or formal QA procedures to be appended to the QA Program. The QA Coordinator shall ensure that all modifications to existing procedures and all new procedures affecting quality are reviewed by the EES QAR and ANL's QASO, approved by the Peer Review Panel Chairman (project manager), and distributed according to the document control procedures for the project. Document control procedures are described in App. C.

\subsection{REFERENCES}

ANL Quality Assurance Policy and Procedures Manual, Argonne National Laboratory (most recently revised on July 31,1985 ). 
Basic Requirements: 5. Instructions, Procedures, and Drawings, in Quality Assurance Program Requirements for Nuclear Facilities, ANSI/ASME NQA-1-1983 Edition, A merican Society of Mechanical Engineers, New York, pp. 2-3 (July 1, 1983).

Quality Assurance Specification for Argonne National Laboratory: Multidisciplinary Peer Reviews of DOE-Contractor Documents for Salt Host-Rock Portion of CRWM Program, U.S. Department of Energy, Salt Repository Project Office, Columbus, Ohio, unpublished document (Sept. 11, 1985). 


\section{QUALITY ASSURANCE PROGRAM}

\section{ARGONNE PEER REVIEW ACTIVITIES FOR THE SALT HOST-ROCK PORTION OF THE CIVILIAN RADIOACTIVE WASTE MANAGEMENT PROGRAM}

\section{SECTION 6}

Document Control 
ARGONNE PEER REVIEW ACTIVITIES FOR THE SALT HOST-ROCK PORTION OF THE CIVILIAN RADIOACTIVE WASTE MANAGEMENT PROGRAM

6 DOCUMENT CONTROL

Project No.: 23562

Page: 1 of 3

Issued: $8 / 12 / 86$

Revision: 0

\subsection{PURPOSE}

Section 6 presents the methods for controlling the preparation, issue, and revision of documents that specify quality requirements or prescribe activities affecting quality to ensure that the correct documents are used.

\subsection{QA REQUIREMENTS}

ANL shall control the preparation, issue, and revision of documents that specify quality requirements or prescribe activities affecting quality to ensure that the correct documents are used. Such documents, including changes thereto, shall be reviewed for adequacy and approved for release by authorized personnel. Controlled copies of the ANL QA Program shall be submitted to SRPO for acceptance before use or after revision.

\subsection{CONTROLLED DOCUMENTS}

The distribution and content of all documents that specify quality requirements or prescribe activities affecting the quality of the peer review process and products shall be controlled. The project QA Program is the primary source of QA information and requirements and standard technical procedures for the peer review task. Therefore, the preparation, approval, distribution, and revision of this program shall follow the document control procedures developed for the peer review task.

\subsection{DOCUMENT CONTROL RESPONSIBILITIES}

\subsubsection{Peer Review Panel Chairman}

As project manager, the Peer Review Panel Chairman has the authority and responsibility for document control for the peer review task. The chairman ensures that individuals performing quality-related activities having preseribed procedures are following approved procedures. Revisions to standard technical procedures affecting quality are prepared by the chairman or members of the core group designated by the 
chairman. The chairman also maintains the distribution list for technical procedures and ensures that the Administrative Secretary distributes controlled copies of new or revised technical procedures to the proper individuals.

\subsubsection{Project QA Coordinator}

The project QA Coordinator is responsible for preparing, obtaining approval, and distributing controlled documents affecting QA procedures and activities. The QA Coordinator maintains the distribution list for controlled QA documents and ensures that the Administrative Secretary distributes copies of new or revised controlled documents to the proper individuals. All controlled QA documents prepared by the QA Coordinator shall be reviewed by the EES QAR and ANL's QASO and approved by the Peer Review Panel Chairman. The QA Coordinator verifies that appropriate document control procedures are followed by the chairman during the preparation and distribution of pertinent technical procedures.

\subsubsection{Administrative Secretary}

The Administrative Secretary is responsible for distributing all controlled documents and for maintaining documentation of the distribution and receipt of these documents for the project QA files.

\subsection{DOCUMENT CONTROL PROCEDURES}

The detailed procedures developed for the preparation, issue, and revision of controlled documents for the peer review task are described fully in App. C.

\subsection{REFERENCES}

ANL Quality Assurance Policy and Procedures Manual, Argonne National Laboratory (July 31, 1985). 
Basic Requirements: 6. Document Control, in Quality Assurance Program Requirements for Nuclear Facilities, ANSI/ASME NQA-1-1983 Edition, American Society of Mechanical Engineers, New York, p. 3 (July 1, 1983).

Quality Assurance Specification for Argonne National Laboratory: Multidisciplinary Peer Reviews of DOE-Contractor Documents for Salt Host-Rock Portion of CRWM Program, U.S. Department of Energy, Salt Repository Project Office, Columbus, Ohio, unpublished document (Sept. 11, 1985). 
QUALITY ASSURANCE PROGRAM

ARGONNE PEER REVIEW ACTIVITIES FOR THE SALT HOST-ROCK PORTION OF THE CIVILIAN RADIOACTIVE WASTE MANAGEMENT PROGRAM

SECTION 7

Control of Purchased Items and Services 


\subsection{PURPOSE}

Section 7 documents procedures for controlling procurement of items and services to ensure conformance with specified requirements.

\subsection{QA REQUIREMENTS}

Procurement of items and services shall be controlled to ensure conformance with specified requirements. Such control shall provide for the following as appropriate: source evaluation and selection, evaluation of objective evidence of quality furnished by suppliers, source inspection, audit, and examination of items or services upon delivery or completion.

\subsection{PROFESSIONAL SERVICES PROCUREMENT}

As stated in Sec. 1, all off-site auxiliary peer review panelists, except those individuals affiliated with other national laboratories, are under contract to ANL. All activities leading to contractual agreements with such individuals are performed by qualified ANL procurement personnel in accordance with established ANL procurement procedures.

\subsection{QA PROCEDURES}

Because auxiliary panelists are selected on the basis of their technical qualifications, and because the work performed under contract is evaluated on the basis of technical criteria, the Peer Review Panel Chairman, the designated Review Session Chairman, and appropriate core group members shall conduct the selection and evaluation activities. Furthermore, because standardized and established procurement procedures are used to obtain the services of contracted panelists, QA review and approval shall be limited to that described in Sec. 4.3 . 
ARGONNE PEER REVIEW ACTIVITIES FOR THE SALT HOST-ROCK PORTION OF THE CIVILIAN RADIOACTIVE WASTE MANAGEMENT PROGRAM

7 CONTROL OF PURCHASED ITEMS AND SERVICES

Project No.: 23562

Page: 2 of 2

Issued: $8 / 12 / 86$

Revision: 0

\subsection{REFERENCES}

ANL Quality Assurance Policy and Procedures Manual, Argonne National Laboratory (most recently revised on July 31, 1985).

Basic Requirements: 7. Control of Purchased Items and Services, in Quality Assurance Program Requirements for Nuclear Facilities, ANSI/ASME NQA-1-1983 Edition, American Society of Mechanical Engineers, New York, p. 3 (July 1, 1983).

Procurement Policy Manual, Argonne National Laboratory (Nov. 1984).

Procurement Procedure Manual, Argonne National Laboratory (most recently revised in March 1985).

Quality Assurance Specification for Argonne National Laboratory: Multidisciplinary Peer Reviews of DOE-Contractor Documents for Salt Host-Rock Portion of CRWM Program, U.S. Department of Energy, Salt Repository Project Office, Columbus, Ohio, unpublished document (Sept. 11, 1985). 


\section{QUALITY ASSURANCE PROGRAM}

ARGONNE PEER REVIEW ACTIVITIES FOR THE SALT HOST-ROCK PORTION OF THE CIVILLAN RADIOACTIVE WASTE MANAGEMENT PROGRAM

\section{SECTION 8}

Identification and Control of Items 
ARGONNE PEER REVIEW ACTIVITIES FOR THE SALT HOST-ROCK PORTION OF THE CIVILIAN RADIOACTIVE WASTE MANAGEMENT PROGRAM

8 IDENTIFICATION AND CONTROL OF ITEMS

Project No.: 23562

Page: 1 of 1

Issued: $8 / 12 / 86$

Revision: 0

\subsection{PURPOSE}

Section 8 considers the applicability of required controis to ensure that correct and accepted items are used or installed.

\subsection{QA REQUIREMENTS}

Controls shall be established to ensure that correct and accepted items are used or installed. Identification shall be maintained either on the items or in documents traceable to the items.

\subsection{APPLICABILITY OF REQUIREMENTS FOR IDENTIFICATION AND CONTROL OF ITEMS}

Because of the type of work performed for the peer review task, the requirements in NQA-1 concerning identification and control of items do not apply and are therefore not addressed in this QA Program.

\subsection{REPERENCES}

Basic Requirements: 8. Identification and Control of ilems, in Quality Assurance Program Requirements for Nuclear Facilities, ANSI/ASME NQA-1-1983 Edition, American Society of Mechanical Engineers, New York, p. 3 (July 1, 1983).

Quality Assurance Specification for Argonne National Laboratory: Multidisciplinary Peer Reviews of DOE-Contractor Documents for Salt Host-Rock Portion of CRWM Program, U.S. Department of Energy, Salt Repository Project Office, Columbus, Ohio, unpublished document (Sept. 11, 1985). 


\section{QUALTY ASSURANCE PROGRAM}

\section{ARGONNE PEER REVIEW ACTIVITIES FOR THE SALT HOST-ROCK PORTION}

OF THE CIVILIAN RADIOACTIVE WASTE MANAGEMENT PROGRAM

SECTION 9

Control of Processes 
ARGONNE PEER REVIEW ACTIVITIES FOR THE SALT HOST-ROCE PORTION OF THE CIVLIAN RADIOACTIVE WASTE MANAGEMENT PROGRAM

9 CONTROL OF PROCESSES

Project No.: 23562

Page: 1 of 1

Issued: $8 / 12 / 86$

Revision: 0

\subsection{PURPOSE}

Section 9 considers the applicability of requirements for control of processes affecting the quality of items or services.

\subsection{QA REQUIREMENTS}

Processes affecting the quality of items or services shall be controlled. Special processes that control or werify quality, such as those used in welding, heat treating, and nondestructive examination, shall be performed by qualified personnel using qualified procedures in accordance with specified requirements.

\subsection{APPLICABILITY OF PROCESS CONTROL REQUIREMENTS}

Because of the type of work performed for the peer review task, the process control requirements in NQA-1 do not apply and are therefore not addressed in this QA Program.

\subsection{REFERENCES}

Basic Requirements: 9. Control of Processes, in Quality Assurance Program Requirements for Nuclear Facilities, ANSI/ASME NQA-1-1983 Edition, American Society of Mechanical Engineers, New York, p. 3 (July 1, 1983).

Quality Assurance Specification for Argonne National Laboratory: Multidisciplinary Peer Reviews of DOE-Contractor Documents for Salt Host-Rock Portion of CRWM Program, U.S. Department of Energy, Salt Repository Project Office, Columbus, Ohio, unpublished document (Sept. 11, 1985). 


\section{QUALITY ASSURANCE PROGRAM}

\section{ARGONNE PEER REVIEW ACTIVITIES FOR THE SALT HOST-ROCK PORTION}

OF THE CIVILIAN RADIOACTIVE WASTE MANAGEMENT PROGRAM

SECTION 10

Inspection 


\section{QUALITY ASSURANCE PROGRAM \\ ARGONNE PEER REVIEW ACTIVTTIES FOR THE SALT HOST-ROCK PORTION \\ OF THE CIVILIAN RADIOACTIVE WASTE MANAGEMENT PROGRAM}

10 INSPECTION

Project No.: 23562

Page: 1 of 3

Issued: $8 / 12 / 86$

Revision: 0

\subsection{PURPOSE}

Section 10 documents procedures for inspecting items or activities to verify conformance with specified requirements.

\subsection{QA REQUIREMENTS}

The following requirements are specified in the referenced documents.

- ANL shall periodically inspect all elements of work connected with the peer review task to verify that adequate management systems are in place to ensure that individual review comments are identified properly upon receipt and are appropriately incorporated into final review documents, that disagreements between reviewers are properly resolved and documented, and that objective evidence (e.g., records) is protected from loss or unauthorized alteration.

- ANL shall specify the items or activities to be inspected to verify compliance with QA requirements and the inspection methods to be employed.

- ANL shall plan, execute, and document the results of the required inspections. Such documentation shall include the procedures used, the peer review items or activities checked, and the inspection results.

- The inspections shall be performed by persons other than those performing or directly supervising the work being inspected. More specifically, inspections can be performed by project personnel, provided they are independent of the peer review process being checked as it relates to a specific technical document. 


\subsection{GENERAL}

"Inspection" in this QA Program refers to the periodic evaluation of work performed for the peer review task to verify that adequate management systems are in place to ensure that procedures affecting quality are appropriate, properly implemented, and followed consistently.

\subsection{INSPECTION PROCEDURES}

Peer review items and activities shall be inspected periodically by the EES QAR or his or her designee, and all inspection findings and results shall be documented. Inspection activities are described in App. D. All inspection documentation shall be maintained in the project QA files. Inspection results shall be reported to the Peer Review Panel Chairman, the Project Manager and QA Manager at SRPO, and appropriate staff at ANL's QASO.

Any deficiencies noted as a result of such inspections shall be reported to these same individuals. The project QA Coordinator, or other appropriate peer review personnel, shall identify and verify implementation of appropriate corrective actions to resolve any identified deficiencies. The QA Coordinator shall assure and document implementation of specified corrective actions. All corrective actions and the ultimate disposition of any identified deficiencies shall be reported as above. The QASO QE shall review all inspection and corrective action documentation to assure compliance with the QA Program.

\subsection{REFERENCES}

Basic Requirements: 10. Inspection, in Quality Assurance Program Requirements for Nuclear Facilities, ANSI/ASME NQA-1-1983 Edition, American Society of Mechanical Engineers, New York, p. 3 (July 1, 1983). 
10 INSPECTION
Project No.: $\mathbf{2 3 5 6 2}$
Page: 3 of 3
Issued: $8 / 12 / 86$
Revision: 0

Quality Assurance Specification for Argonne National Laboratory: Multidisciplinary Peer Reviews of DOE-Contractor Documents for Salt Host-Rock Portion of CRWM Program, U.S. Department of Energy, Salt Repository Project Office, Columbus, Ohio, unpublished document (Sept. 11, 1985).

ANL Quality Assurance Policy and Procedures Manual, Argonne National Laboratory (most recently revised on July 31,1985 ). 


\section{QUALITY ASSURANCE PROGRAM}

ARGONNE PEER REVIEW ACTIVITIES FOR THE SALT HOST-ROCK PORTION OF THE CIVILIAN RADIOACTIVE WASTE MANAGEMENT PROGRAM

SECTION 11

Test Control 


\subsection{PURPOSE}

Section 11 considers the applicability of required testing to verify the conformance of an item with specified requirements and to demonstrate that items will perform satisfactorily in service.

\subsection{QA REQUIREMENTS}

Tests to verify conformance of an item with specified requirements and to demonstrate that items will perform satisfactorily in service shall be planned and executed. The characteristics to be tested and the test methods to be employed shall be specified. The test results shall be documented, and their conformance with acceptance criteria shall be evaluated.

\subsection{APPLICABILITY OF TEST CONTROL REQUIREMENTS}

Because of the type of work performed for the peer review task, the test control reguirements in NQA-1 do not apply and are therefore not addressed in this QA Program.

\subsection{REFERENCES}

Basic Requirements: 11. Test Control, in Quality Assurance Program Requirements for Nuclear Facilities, ANSI/ASME NQA-1-1983 Edition, American Society of Mechanical Engineers, New York, p. 3 (July 1, 1983).

Quality Assurance Specification for Argonne National Laboratory: Multidisciplinary Peer Reviews of DOE-Contractor Documents for Salt Host-Rock Portion of CRWM Program, U.S. Department of Energy, Salt Repository Project Office, Columbus, Ohio, unpublished document (Sept. 11, 1985). 
QUALITY ASSURANCE PROGRAM

ARGONNE PEER REVIEW ACTIVITIES FOR THE SALT HOST-ROCK PORTION OF THE CIVILLAN RADIOACTIVE WASTE MANAGEMENT PROGRAM

SECTION 12

Control of Measuring and Test Equipment 
FOR ARGONNE PEER REVIEW ACTIVITIES FOR THE SALT HOST-ROCK PORTION OF THE CIVILIAN RADIOACTIVE WASTE MANAGEMENT PROGRAM

12 CONTROL GF MEASURING AND TEST EQUIPMENT

$$
\begin{aligned}
\text { Project No.: } & 23562 \\
\text { Page: } & 1 \text { of } 1 \\
\text { Issued: } & 8 / 12 / 86 \\
\text { Revision: } & 0
\end{aligned}
$$

\subsection{PURPOSE}

Section 12 considers the applicability of control requirements for measuring and test equipment used for activities affecting quality and requirements for periodic equipment calibration and adjustment.

\subsection{QA REQUIREMENTS}

Tools, gages, instruments, and other measuring and test equipment used for activities affecting quality shall be controlled and at specified intervals calibrated and adjusted to maintain accuracy within necessary limits.

\subsection{APPLICABILITY OF MEASURING AND TEST EQUIPMENT CONTROLS}

Because of the type of work performed for the peer review task, the control requirements in NQA-1 for measuring and test equipment do not apply and are therefore not addressed in this QA Program.

\subsection{REFERENCES}

Basic Requirements: 12. Control of Measuring and Test Equipment, in Quality Assurance Program Requirements for Nuclear Facilities, ANSI/ASME NQA-1-1983 Edition, American Society of Mechanical Engineers, New York, p. 3 (July 1, 1983).

Quality Assurance Specification for Argonne National Laboratory: Multidisciplinary Peer Reviews of DOE-Contractor Documents for Salt Host-Rock Portion of CRWM Program, U.S. Department of Energy, Salt Repository Project Office, Columbus, Ohio, unpublished document (Sept. 11, 1985). 


\section{QUALITY ASSURANCE PROGRAM}

\section{ARGONNE PEER REVIEW ACTIVTTIES FOR THE SALT HOST-ROCK PORTION}

OF THE CIVILLAN RADIOACTIVE WASTE MANAGEMENT PROGRAM

SECTION 13

Handling, Storage, and Shipping 
ARGONNE PEER REVIEW ACTIVITIES FOR THE SALT HOST-ROCE PORTION

OF THE CIVILIAN RADIOACTIVE WASTE MANAGEMENT PROGRAM

13 HANDLING, STORAGE, AND SHIPPING

Project No.: $\mathbf{2 3 5 6 2}$

Page: 1 of 1

Issued: $8 / 12 / 86$

Revision: 0

\subsection{PURPOSE}

Section 13 considers the applicability of requirements for the handling, storing, cleaning, packaging, shipping, and preserving of items to prevent damage or loss and to minimize deterioration.

\subsection{QA REQUIREMENTS}

The handling, storing, cleaning, packaging, shipping, and preserving of items shall be controlled to prevent damage or loss and to minimize deterioration.

\subsection{APPLICABILITY OF HANDLING, STORAGE, AND SHIPPING REQUIREMENTS}

Because of the nature of the work performed for the peer review task, the handling, storage, and shipping requirements in NQA-1 do not apply and are therefore not addressed in this QA Program.

\subsection{REFERENCES}

Basic Requirements: 13. Handling, Storage, and Shipping, in Quality Assurance Program Requirements for Nuclear Facilities, ANSI/ASME NQA-1-1983 Edition, American Society of Mechanical Engineers, New York, p. 3 (July 1, 1983).

Quality Assurance Specification for Argonne National Laboratory: Multidisciplinary Peer Reviews of DOE-Contractor Documents for Salt Host-Rock Portion of CRWM Program, U.S. Department of Energy, Salt Repository Project Office, Columbus, Ohio, unpublished document (Sept. 11, 1985). 


\section{QUALITY ASSURANCE PROGRAM}

ARGONNE PEER REVIEW ACTIVITIES FOR THE SALT HOST-ROCK PORTION OF THE CIVILIAN RADIOACTIVE WASTE MANAGEMENT PROGRAM

\section{SECTION 14}

Inspection, Test, and Operating Status 
FOR ARGONNE PEER REVIEW ACTIVITIES FOR THE SALT HOST-ROCK PORTION OF THE CIVILIAN RADIOACTIVE WASTE MANAGEMENT PROGRAM

14 INSPECTION, TEST, AND OPERATING STATUS

$\begin{aligned} \text { Project No.: } & 23562 \\ \text { Page: } & 1 \text { of } 1 \\ \text { Issued: } & 8 / 12 / 86 \\ \text { Revision: } & 0\end{aligned}$

\subsection{PURPOSE}

Section 14 considers the applicability of measures for documenting the inspection, test, and operating status of items.

\subsection{QA REQÚIREMENTS}

The status of inspection and test activities shall be identified, either on the items or in documents traceable to the items, in cases where it is necessary to ensure that required inspections and tests are performed and that items that have not passed the required inspections and tests are not inadvertently installed, used, or operated. Status shall be maintained through physical location and tags, markings, shop travelers, stamps, inspection records, or other suitable means. The authority for applying and removing tags, markings, labels, and stamps shall be specified. The status indicators shall also indicate the operating status of systems and components of the nuclear facility, such as by tagging valves and switches, to prevent inadvertent operation.

\subsection{APPLICABILITY OF INSPECTION, T'EST, AND OPERATING STATUS REQUIREMENTS}

Because of the type of work performed for the peer review task, the requirements in NQA-1 for documenting the inspection, test, and operating status of items do not apply and are therefore not addressed in this QA Program.

\subsection{REFERENCES}

Basic Requirements: 14. Inspection, Test, and Operating Status, in Quality Assurance Program Requirements for Nuclear Facilities, ANSI/ASME NQA-1-1983 Edition, American Society of Mechanical Engineers, New York, p. 3 (July 1, 1983).

Quality Assurance Specification for Argonne National Laboratory: Multidisciplinary Peer Reviews of DOE-Contractor Documents for Salt Host-Rock Portion of CRWM Program, U.S. Department of Energy, Salt Repository Project Office, Columbus, Ohio, unpublished document (Sept. 11, 1985). 
QUALITY ASSURANCE PROGRAM

ARGONNE PEER REVIEW ACTIVITIES FOR THE SALT HOST-ROCK PORTION

OF THE CIVLIAN RADIOACTIVE WASTE MANAGEMENT PROGRAM

\section{SECTION 15}

Control of Nonconforming Items 
FOR ARGONNE PEER REVIEW ACTIVITIES FOR THE SALT HOST-ROCK PORTION OF THE CIVILIAN RADIOACTIVE WASTE MANAGEMENT PRCGRAM

15 CONTROL OF NONCONFORMING ITEMS

Project No.: 23562

Page: 1 of 4

Issued: $8 / 12 / 86$

Revision: 0

\subsection{PURPOSE}

Section 15 presents the requirements and responsibilities for identification, documentation, evaluation, and disposition of nonconforming items.

\subsection{QA REQUIREMENTS}

The following QA requirements are specified in the referenced documents.

- ANL shall control items that do not conform to specified requirements to prevent inadvertent installation or use. Provision shall be made for identification, documentation, evaluation, segregation (when practical), and disposition of nonconforming items, and affected organizations shall be notified.

- ANL shall identify nonconforming items by marking, tagging, or other methods that do not adversely affect the end use of the item. Such identifications shall be legible and easily recognizable. If it is not practical to identify each nonconforming item, the container, package, or segregated storage area, as appropriate, shall be identified.

- ANL shall segregate nonconforming items, when practical, by placing them in a clearly identified and designated hold area until they can be properly disposed of. When segregation is impractical or impossible because of physical conditions such as size, weight, or access limitations, other precautions shall be documented and employed to preclude inadvertent use of nonconforming items.

- ANL shall review nonconforming conditions of the item or activity and recommend and approve dispositions in accordance with 
procedures. Further processing, delivery, installation, or use of a nonconforming item shall be controlled, pending evaluation and approved disposition by authorized personnel. ANL shall define the responsibility and authority for evaluation and disposition of nonconforming items.

- Personnel performing evaluations to determine disposition shall be demonstrably competent in the specific area being evaluated, adequately understand the requirements, and have access to any pertinent background information.

- ANL shall identify and document the final disposition (e.g., use as is, reject, repair, or rework) of nonconforming items. ANL shall also document the technical justification for accepting a noneonforming item, for designating it as an item to be repaired, or using it as is. The "as-built" records, if such records are required, shall reflect the accepted deviation. Repaired or reworked items shall be reexamined in accordance with applicable procedures and the original acceptance criteria, unless alternative acceptance criteria have been established.

- ANL shall implement QA measures for periodic analysis of nonconformance reports to discern quality trends and to help identify root causes of nonconformances. The results of these reviews and analyses shall be documented and reported to upper management for review and assessment.

- ANL shall evaluate all nonconformances to see whether they merit reporting as incidents. An incident, for this purpose, is defined as 
an event that causes a deviation from the planined or expected result of an activity or course of events, which has or could have significant programmatic (reliability, cost, or schedule), safety, health, or environmental impact.

- ANL shall transmit copies of all nonconformance reports to SRPO for review and concurrence.

\subsection{GENERAL}

The NQA-1 document generally refers to hardware-type items that do not conform to specified requirements as "nonconforming items." This connotation does not apply to the peer review task because of the nature of the work. Although a "nonconforming item" could be any documentation or record of some phase of a review activity that contains or relates to an identified inadequacy, the designation "nonconforming item" is reserved primarily for completed peer review reports identified as containing errors or omissions of such significance that the content of the report is of questionable or clearly deficient quality.

The more inclusive term "ncnconformance" is generally defined as a deficiency in characteristic, documentation, or procedure that renders the quality of an item or activity unacceptable or indeterminate. In the case of the peer review task, any deviation from established procedures of such significance that the quality of the review activity or resulting review report is unacceptable or indeterminate is considered a nonconformance. The identification of nonconformances shall be documented in nonconformance reports or memoranda.

\subsection{RESPONSIBILITIES}

The project QA Coordinator is responsible for routine monitoring of project activities for the purpose of determining compliance with the QA Program. The QA 
FOR ARGONNE PEER REVIEW ACTIVITIES FOR THE SALT HOST-ROCK PORTION

OF THE CIVILIAN RADIOACTIVE WASTE MANAGEMENT PROGRAM

15 CONTROL OF NONCONFORMING ITEMS

Project No.: 23562

Page: 4 of 4

Issued: $8 / 12 / 86$

Revision: 0

Coordinator shall prepare reports covering these monitoring activities; such reports shall include discussions of any identified nonconformances and all related corrective actions. These reports and associated documentation shall be distributed to key project, EES, ANL, and SRPO personnel. The QA Coordinator also ensures that appropriate actions are taken to correct and resolve all identified nonconformances. The QA Coordinator evaluates all nonconformances to see whether they merit reporting as unusual occurrences and periodically analyzes nonconformance reports to discern quality trends and to help identify root causes of nonconformance.

Project personnel shall inform the QA Coordinator whenever instances of nonconformance are known or suspected.

The Peer Review Panel Chairman shall approve the disposition of nonconformances that cannot be corrected so as to be in conformance with the QA Program.

\subsection{PROCEDURES FOR CONTROLLING NONCONFORMANCES}

The procedures developed for identification, documentation, evaluation, and disposition of nonconformances are presented in App. E.

\subsection{REFERENCES}

Basic Requirements: 15. Control of Nonconforming Items and Supplement 15S-1: Supplementary Requirements for the Control of Nonconforming Items, in Quality Assurance Program Requirements for Nuclear Facilities, ANSI/ASME NQA-1-1983 Edition, American Society of Mechanical Engineers, New York, pp. 3 and 30 (July 1, 1983).

Quality Assurance Specification for Argonne National Laboratory: Multidisciplinary Peer Reviews of DOE-Contractor Documents for Salt Host-Rock Portion of CRWM Program, U.S. Department of Energy, Salt Repository Project Office, Columbus, Ohio, unpublished document (Sept. 11, 1985).

ANL Quality Assurance Policy and Procedures Manual, Argonne National Laboratory (most recently revised on July 31,1985 ). 


\section{QUALITY ASSURANCE PROGRAM}

ARGONNE PEER REVIEW ACTIVITIES FOR THE SALT HOST-ROCK PORTION OF THE CIVILIAN RADIOACTIVE WASTE MANAGEMENT PROGRAM

SECTION 16

Corrective Action 


\subsection{PURPOSE}

Section 16 defines the actions to be taken to correct any identified significant condition that is adverse to quality.

\subsection{QA REQUIREMENTS}

The following requirements are contained in the referenced documents.

- ANL shall identify promptly and correct as soon as practical any conditions adverse to quality. In the case of a significant condition adverse to quality, ANL shall determine the cause of the condition and take corrective action to preclude recurrence. Significant conditions adverse to quality include but are not necessarily limited to failure to implement major elements of the QA Program; deficiencies in the use of instructions or procedures; failure to implement corrective action in response to inspection, surveillance, and audits; and unexpected damage to or loss of review documentation.

- ANL shall document and report to appropriate levels of management for review and assessment the identification, cause, and corrective action for significant conditions adverse to quality. Proper implementation of the corrective action shall be verified by the ANL QA organization.

- ANL shall complete corrective actions in a timely manner.

- ANL shall formally respond to any SRPO-issued requests for corrective action in the manner and time indicated in the transmittal letter. 


\section{ARGONNE PEER REVIEW ACTIVITIES FOR THE SALT HOST-ROCK PORTION}

OF THE CIVLIAN RADIOACTIVE WASTE MANAGEMENT PROGRAM

16 CORRECTIVE ACTION

Project No.: 23562

Page: 2 of 3

Issued: $8 / 12 / 86$

Revision: 0

\subsection{SIGNIFICANT QUALITY PROBLEMS}

In general terms, significant conditions adverse to quality are those which, if uncorrected, could have a serious effect on the achievement or verification of quality for the peer review task. Achieving quality entails conducting quality-related activities in accordance with applicable technical requirements and good work practices. Verifying quality requires an independent determination that quality-related activities were accomplished in an adequate manner and in accordance with specified technical and administrative procedures. Some situations and conditions considered to be significantly adverse to quality are presented in Sec. 16.2.

When a problem adverse to quality is determined to be significant, ANL shall determine the cause of the condition and take corrective action to preclude recurrence. The initial determination of significance shall be made by the project QA Coordinator, and the Peer Review Panel Chairman shall concur with such designation. Adverse conditions and corrective actions taken shall be documented in corrective action reports or memoranda.

\subsection{RESPONSIBILITIES}

\subsubsection{Peer Review Panel Chairman}

As project manager, the Peer Review Panel Chairman shall ensure that controls are established and implemented to identify, document, and correct significant conditions adverse to quality. The chairman is also responsible for informing the QA Coordinator of all potentially significant conditions adverse to quality, either known or suspected.

\subsubsection{Core Group Peer Review Staff}

Each member of the core peer review group staff shall identify and report to the QA Coordinator potentially significant conditions adverse to quality that are known or suspected. 


\subsubsection{Project QA Coordinator}

The project QA Coordinator shall develop and administer the corrective action reporting system for the peer review task. The coordinator also has primary responsibility for initiating and distributing corrective actions reports to appropriate management personnel. The coordinator shall ensure that identified significant quality problems are reported and corrected in a timely manner.

\subsection{CORRECTIVE ACTION PROCEDURES}

Procedures developed for identifying significant conditions adverse to quality and for implementing corrective actions are Cescribed in App. E.

\subsection{REFERENCES}

Basic Requirement: 16. Corrective Action, in Quality Assurance Program Requirements for Nuclear Facilities, ANSI/ASME NQA-1-1983 Edition, American Society of Mechanical Engineers, New York, p. 4 (July 1, 1983).

Quality Assurance Specification for Argonne National Laboratory: Multidisciplinary Peer Reviews of DOE-Contractor Documents for Salt Host-Rock Portion of CRWM Program, U.S. Department of Energy, Salt Repository Project Office, Columbus, Ohio, unpublished document (Sept. 11, 1985).

ANL Quality Assurance Policy and Procedures Manual, Argonne National Laboratory (most recently revised on July 31,1985 ). 


\section{QUALITY ASSURANCE PROGRAM}

ARGONNE PEER REVIEW ACTIVITIES FOR THE SALT HOST-ROCK PORTION OF THE CIVILIAN RADIOACTIVE WASTE MANAGEMENT PROGRAM

SECTION 17

Quality Assurance Records 
ARGONNE PEER REVIEW ACTIVITIES FOR THE SALT HOST-ROCK PORTION

OF THE CIVILIAN RADIOACTIVE WASTE MANAGEMENT PROGRAM

\subsection{PURPOSE}

Section 17 describes the requirements and responsibilities for specifying, preparing, maintaining, and distributing records that document quality.

\subsection{QA REQUIREMENTS}

The following QA requirements are specified in the referenced documents.

- ANL shall specify, prepare, and maintain records that furnish documentary evidence of quality.

- Records shall be legible, identifiable, and retrievable.

- ANL shall protect records against damage, deterioration, and loss.

- ANL shall establish and document requirements and responsibilities for records transmittal, distribution, retention, maintenance, and disposition.

- ANL shall maintain dual copies of QA records; the originals shall be submitted to SRPO in records turnover. Originals of records that are not of reproducible quality shall be so identified. A reconstructed original or reproducible copy, and the identified unusable original, shall be included in the records turnover. Also, proprietary and copyrighted materials shall be identified in writing to the SRPO Project Manager before records turnover.

- Magnetic tapes and all necessary information needed to read or duplicate them shall be included in the records turnover. 


\section{QUALITY ASSURANCE PROGRAM \\ ARGONNE PEER REVIEW ACTIVITIES FOR THE SALT HOST-ROCK PORTION OF THE CIVILIAN RADIOACTIVE WASTE MANAGEMENT PROGRAM}

17 QUALITY ASSURANCE RECORDS

Project No.: 23562

Page: 2 of 5

Issued: $8 / 12 / 86$

Revision: 0

Computer software and appropriate user's manuals shall also be included in the records turnover.

- ANL shall prepare and submit to the SRPO Project Manager for review and acceptance a project records list organized by subject that identifies the specific types of records to be maintained in the project records files. The locations of storage areas for physical samples shall also be included. The list shall be updated periodically as work progresses. Updated lists, like the original list, shall be submitted to SRPO for acceptance.

- ANL shall assemble, file, index, and store on a continuing basis all records generated pursuant to the peer review task contract. As each document or sample becomes a QA record, it shall be entered into the system. ANL shall also maintain a records file index, which shall list by subject all the record types contained in the system, identify the record type in sufficient detail to clearly establish the specific relationship of that record to the work activity, and identify the location of that record or the name of the individual holding the record.

- Although ANL will normally submit records to SRPO on a regular basis as part of the annual records turnover, SRPO may request records to be submitted more frequently.

- SRPO shall transmit to ANL written instructions for collecting and packaging records for records turnover and any forms to be completed by ANL. 


\subsection{RESPONSIBILITIES}

\subsubsection{Peer Review Panel Chairman}

The Peer Review Panel Chairman (project manager) ensures that adequate controls are established for identifying, preparing, storing, and maintaining records that furnish evidence of the quality of the peer review process and results.

\subsubsection{Core Peer Review Group Staff}

All members of the core peer review group, including its chairman, are responsible for identifying documentary evidence that should be part of the QA records, for generating QA records to document quality-related activities, for transmitting all QA record materials to the Administrative Secretary for processing, and for maintaining a working knowledge of current QA documentation requirements for peer review activities.

\subsubsection{Administrative Secretary}

The Administrative Secretary maintains the project QA files, which document project activities. Therefore, this individual must be familiar with and capable of correctly implementing appropriate procedures pertaining to QA records. He or she shall organize, file, retrieve, and control all project QA records.

\subsubsection{Project QA Coordinator}

The project QA Coordinator is responsible for developing appropriate QA procedures for specifying, preparing, and maintaining project records. The QA Coordinator is also responsible for verifying that proper QA procedures pertaining to project records are followed; for ensuring that records are protected against loss, damage, or deterioration; for designating the retention period of project QA records; and for ensuring that the necessary records are turned over to SRPO in an appropriate manner. 
OF THE CIVILIAN RADIOACTIVE WASTE MANAGEMENT PROGRAM

17 QUALITY ASSURANCE RECORDS
Project No.: 23562
Page: 4 of 5
Issued: $8 / 12 / 86$
Revision: 0

\subsection{DOCUMEN'IATION OF THE PEER REVIEW PROCESS}

Figure 17.1 shows the standard QA records documentation process for the ANL peer review task. Each item illustrated in this figure is prepared and maintained in the project QA files for each peer review performed by ANL for SRPO.

\subsection{IMPLEMENTATION PROCEDURES FOR QA RECORDS}

ANL shall devise a procedural and organizational scheme for preparing, maintaining, and distributing any documentation of peer review activities that affects quality. Appendix $\mathrm{F}$ describes these procedures in detail.

\subsection{REFERENCES}

Basic Requirements: 17. Quality Assurance Records and Supplement 17S-1: Supplementary Requirements for Quality Assurance Records, in Quality Assurance Program Requirements for Nuclear Facilities, ANSI/ASME NQA-1-1983 Edition, American Society of Mechanical Engineers, New York, pp. 4 and 31-33 (Juily 1, 1983).

Quality Assurance Specification for Argonne National Laboratory: Multidisciplinary Peer Reviews of DOE-Contractor Documents for Salt Host-Rock Portion of CRWM Program, U.S. Department of Energy, Salt Repository Project Office, unpublished document (Sept. 11, 1985).

ANL Quality Assurance Policy and Procedures Manual, Argonne National Laboratory (most recently revised on July 31,1985 ). 

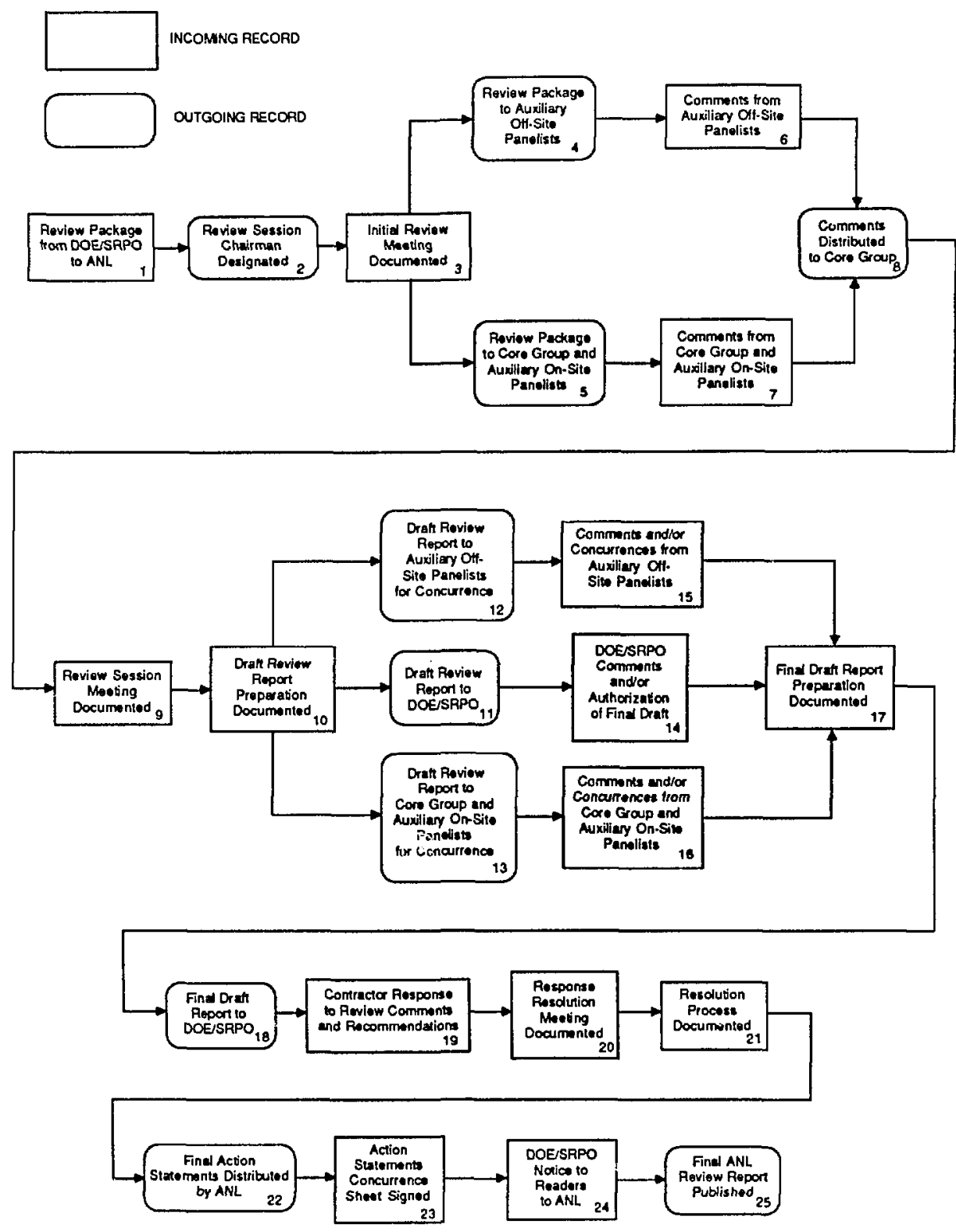

FIGURE 17.1 QA Documentation of the ANL Peer Review Process 


\section{QUALITY ASSURANCE PROGRAM}

ARGONNE PEER REVIEW ACTIVITIES FOR THE SALT HOST-ROCK PORTION OF THE CIVILIAN RADIOACTIVE WASTE MANAGEMENT PROGRAM

SECTION 18

Audits 


\subsection{PURPOSE}

Section 18 considers the applicability of planned and scheduled audit requirements for verifying compliance with all aspects of the QA Program and to determine the program's effectiveness.

\subsection{RA REQUIREMENTS}

Planned and scheduled audits shall be yerformed to verify compliance with all aspects of the QA Program and to determine the program's effectiveness. These audits shall be carried out in accordance with written procecures or checklists by personnel who are not directly responsible for performing the activities being audited. Audit results shall be documented and then reported to and reviewed by responsible management. Follow-up action shall be taken if indicated.

\subsection{APPLICABILITY OF AUDIT REQUIREMENTS}

Internal to the peer review task, ANL shall verify compliance with the QA Program and determine its effectiveness through the inspection or surveillance procedures described in Sec. 10 and App. D. Externally, QA personnel from ANL's QASO and SRPO can audit peer review QA activities at their discretion. Such audits shall be conducted by $\mathrm{QA}$ persons not connected with the peer review task, in accordance with procedures established by the ANL and DOE QA programs. Therefore, audit requirements and procedures are not addressed in this QA Program.

\subsection{REFERENCES}

Basic Requirements: 18. Audits, in Quality Assurance Program Requirements for Nuclear Facilities, ANSI/ASME NQA-1-1983 Edition, American Society of Mechanical Engineers, New York, p. 4 (July 1, 1983). 
Quality Assurance Specification for Argonne National Laboratory: Multidisciplinary Peer Reviews of DOE-Contractor Documents for Salt Host-Rock Portion of CRWM Program, U.S. Department of Energy, Salt Repository Project Office, Columbus, Ohio, unpublished document (Sept. 11, 1985).

ANL Quality Assurance Policy and Procedures Manuai, Argonne National Laboratory (most recently revised on July 31,1985 ). 


\section{QUALITY ASSURANCE PROGRAM}

\section{ARGOHNE PEER REVIEW ACTIVITIES FOR THE SALT HOST-ROCK PORTION}

OF THE CIVILIAN RADIOACTIVE WASTE MANAGEMENT PROGRAM

\section{SECTION 19}

Deliverable Data and Reporting Requirements 


\section{QUALITY ASSURANCE PROGRAM \\ ARGONNE PEER REVIEW ACTIVITIES FOR THE SALT HOST-ROCK PORTION \\ OF THE CIVILIAN RADIOACTIVE WASTE MANAGEMENT PROGRAM}

19 DELIVERABLE DATA AND REPORTING REQUIREMENTS

Project No.: 23562

Page: 1 of 2

Issued: $8 / 12 / 86$

Revision: 0

\subsection{PURPOSE}

Section 19 identifies the deliverable data and reporting requirements for the peer review task.

\subsection{QA REQUIREMENTS}

- ANL shall furnish the QA deliverables identified and described in SRPO'S QA specification for the ANL peer review task.

- ANL shall submit to SRPO a monthly summary of QA-related activities. This summary shall include, as appropriate, changes in organizational structure; changes in project or QA responsibilities, or in lead technical and scientific personnel; changes in the QA Program; changes in the review, test, or audit and surveillance schedules; results of ANL-implemented internal and external QA inspections; and status of corrective actions resulting from inspection, disposition of nonconformances, and reported incidents. Copies of audit/surveillance and nonconformance reports or memoranda shall also be included in the monthly summary.

- ANL shall immediately report to the SRPO Project Manager and SRPO QA Manager all incidents that result in deviation from the planned or expected outcome of an activity or course of events that could have significant programmatic (reliability, cost, or schedule), safety, health, or environmental impact. Verbal notification shall take place within 48 hours and written notification within 14 calendar days from initial notification.

- In its QA reports, ANL shall, based on available information, identify the organization involved and the location where the 
ARGONNE PEER REVIEW ACTIVITIES FOR THE SALT HOST-ROCK PORTION OF THE CIVILIAN RADIOACTIVE WASTE MANAGEMENT PROGRAM

19 DELIVERABLE DATA AND REPORTING REQUIREMENTS $\begin{aligned} & \text { Project No.: } 23562 \\ & \text { Page: } 2 \text { of } 2 \\ & \text { Issued: } 8 / 12 / 86 \\ & \text { Revision: } 0\end{aligned}$

incident occurred; describe when, how, and why the incident took place; deseribe what caused the incident and its immediate effects; and indicate what corrective action is recommended or has been taken.

- ANL shall be notified in writing of SRPO's evaluation of the problem. SRPO shall state whether any or any further corrective action is required, or if the problem is closed, meaning that no further action is required.

- ANL shall immediately report to SRPO when the QA Program cannot for any reason be established, implemented, or maintained.

\subsection{DELIVERABLE DATA AND REPORTING REQUIREMENTS}

The deliverable data and reporting requirements for ANL peer review QA activities as contrined in the QA specification prepared by SRPO are presented in App. G.

\subsection{RESPONSIBILITIES}

The Peer Review Panel Chairman ensures that all deliverable data and reporting requirements for the peer review task are met. The QA Coordinator for the peer review task ensures that all deliverable data and reporting requirements related to project QA activities are satisfied.

\subsection{REFERENCES}

Quality Assurance Specification for Argonne National Laboratory: Multidisciplinary Peer Reviews of DOE-Contractor Documents for Salt Host-Rock Portion of CRWM Program, U.S. Department of Energy, Salt Repository Project Office, Columbus, Ohio, unpublished document (Sept. 11, 1985). 


\section{QUALITY ASSURANCE PROGRAM}

\section{ARGONNE PEER REVIEW ACTIVITIES FOR THE SALT HOST-ROCK PORTION OF THE CIVILIAN RADIOACTIVE WASTE MANAGEMENT PROGRAM}

APPENDIX A

Correspondence between SRPO Quality Assurance Specification and AN!, Quality Assurance Program 
APPENDIX A: Correspondence between SRPO

QA Specification and ANL QA Program
Project No.: 23562

Page: 1 of 3

Issued: $8 / 12 / 86$

Revision: 0

Table A.1 shows the correspondence between the individual elements of SRPO's QA specification for the ANL multidisciplinary peer review task and the QA Plan and associated procedures for this task, as detailed in this document. All elements of the specification are identified by number in the first column. The second column contains the corresponding section number(s) where the content or perceived intent of the individual specification element is addressed in this QA Program. 
APPENDIX A: Correspondence between SRPO

QA Specification and ANL QA Program
Project No.: 23562

Page: 2 of 3

Issued: $8 / 12 / 86$

Revision: 0

TABLE A.1 Correspondence between SRPO

QA Specification and ANL QA Program

Elements

\begin{tabular}{|c|c|}
\hline $\begin{aligned} \text { SRF } & \text { QA } \\
\text { Specif } & =a t i o n \\
\text { Ele } & \text { ant }\end{aligned}$ & $\begin{array}{c}\text { ANL Peer } \\
\text { Review QA } \\
\text { Program Element }\end{array}$ \\
\hline A. 1 & \\
\hline $\begin{array}{l}\text { A. } 1.1 \\
\text { A. } 1.2\end{array}$ & $\begin{array}{l}\text { Foreword, all } \\
\text { All }\end{array}$ \\
\hline A. 2 & \\
\hline A. 2.1 & NA* \\
\hline A. $3^{-2.2}$ & NA \\
\hline A. 3.1 & 19, App. G \\
\hline A. 3.2 & 19, App. G \\
\hline A. 3.3 & 19, App. G \\
\hline A.3.3.a & 19, App. G \\
\hline $\begin{array}{l}\text { A. } 3 \cdot 3 \cdot b \\
\text { A. } 3 \cdot 3 \cdot C\end{array}$ & $\begin{array}{l}19, \text { App. G } \\
\text { NA }\end{array}$ \\
\hline A.3.4 & 19, App. G \\
\hline A. 4 & \\
\hline A. $5^{A .4}$ & $2.7,2.8$ \\
\hline $\begin{array}{l}A .5 .1 \\
1.0\end{array}$ & NA \\
\hline 1.1 & 1 \\
\hline $2.0^{1.1 .1}$ & Figs. $1.1,1.2,1.3,1.4$ \\
\hline 2.1 & A11 \\
\hline 2.2 & 2.6, App. C, App. G \\
\hline $\begin{array}{r}2.3 \\
2.3 .1\end{array}$ & $\begin{array}{l}\text { All } \\
\text { All }\end{array}$ \\
\hline 2.4 & A11 \\
\hline 2.5 & 2.6 \\
\hline $\begin{array}{l}2.6 \\
3.0\end{array}$ & $2.5,17$, App. F \\
\hline 3.1 & NA \\
\hline
\end{tabular}


APPENDIX A: Correspondence between SRPC

QA Specification and ANL QA Program
Project No.: 23562

Page: 3 of 3

Issued: $8 / 12 / 86$

Revision: 0

TABLE A.1 (Cont'd)

\begin{tabular}{|c|c|}
\hline $\begin{array}{l}\text { SRPO QA } \\
\text { Specification } \\
\text { Element }\end{array}$ & $\begin{array}{c}\text { ANL Peer } \\
\text { Review QA } \\
\text { Program Element }\end{array}$ \\
\hline $\begin{array}{l}3.2 \\
3.2 .1 \\
3.2 .2 \\
3.2 .3 \\
3.2 .4 \\
3.2 .5 \\
3.2 .5 . a \\
3.2 .4 . b \\
3.2 .6\end{array}$ & $\begin{array}{l}\text { 3, App. B } \\
\text { App. B } \\
\text { App. B, App. } \mathrm{F} \\
\text { App. B } \\
\text { App. B } \\
\text { App. B } \\
\text { App. B } \\
\text { App. B } \\
1,2,3, \text { App. B, App. } F\end{array}$ \\
\hline $\begin{array}{l}10.0 \\
10.1 \\
10.2 \\
10.3\end{array}$ & $\begin{array}{l}10 \\
10 \\
10, \text { App. D, App. F }\end{array}$ \\
\hline $\begin{array}{l}15.0 \\
15.1 \\
15.2 \\
15.3\end{array}$ & $\begin{array}{l}15, \text { App. } E \\
15, \text { App. } E, \text { App. } G \\
15, \text { App. } E, \text { App. G }\end{array}$ \\
\hline $\begin{array}{r}16.0 \\
16.1 \\
16.2\end{array}$ & $\begin{array}{l}\text { 16, App. E } \\
16, \text { App. E }\end{array}$ \\
\hline $\begin{array}{l}17.0 \\
17.1 \\
17.2 \\
17.3 \\
17.4 \\
17.5 \\
17.6\end{array}$ & $\begin{array}{l}\text { NA } \\
17, \text { App. F } \\
17 \text {, App. F, App. G } \\
17 \text {, App. F } \\
17, \text { App. F, APP. G } \\
\text { NA }\end{array}$ \\
\hline
\end{tabular}

*Elements indicated as "NA" are not specifically addressed in a particular section of the QA Program because those elements are of a general nature and are included in the QA specification for information or clarification only. 


\section{QUALITY ASSURANCE PROGRAM}

ARGONNE PEER REVIEW ACTIVITIES FOR THE SALT HOST-ROCK PORTION OF THE CIVILIAN RADIOACTIVE WASTE MANAGEMENT PROGRAM

APPENDIX B

QAP-1, Design Control Procedures 
ARGONNE PEER REVIEW ACTIVITIES FOR THE SALT HOST-ROCK PORTION OF THE CIVILIAN RADIOACTIVE WASTE MANAGEMENT PROGRAM

APPENDIX B: QAP-1, Design Control Procedures
Project No.: 23562

Page: 1 of 14

Issued: $8 / 12 / 86$

Revision: 0

\section{B.1 GENERAL}

The SRPO verification process requires having a contractor's work evaluated for adequacy and accuracy by persons who are independent of the contractor and who are technically competent to judge the work. The ANL peer review activities provide a key element for such verification. Appendix B details the QA procedures used by ANL to ensure the quality of the peer review process and results.

\section{B.2 SELECTION AND APPROVAL OF CORE PEER REVIEW GROUP MEMBERS}

As shown in Fig. 1.4 and discussed in Sec. 1.7 of the QA Plan, the ANL Peer Review Panel consists of both core peer review group members and auxiliary panelists. The Peer Review Panel Chairman was designated by SRPO. The chairman subsequently identified and selected individuals for the core group with appropriate knowledge and expertise as determined from anticipated review needs and requirements, as well as through interactions with SRPO staff. The credentials of the individuals selected were transmitted to SRPO for evaluation and approval.

As additional core group members are needed to meet SRPO review requirements, individuals with the requisite technical qualifications shall be identified by the chairman, and documentation of each candidate's experience shall be provided to the SRPO Deputy Project Manager, who is also the SRPO Project Manager for the peer review project, for examination. A formal letter of approval for an individual to serve as a core group member shall be provided to the Peer Review Panel Chairman by SRPO. Such approvals, along with the nominating letter from the Peer Review Panel Chairman, and any related correspondence, shall become QA records and shall be maintained in the peer review project $Q A$ files.

If, for any reason, a candidate core group member is not immediately approved by SRPO, the issue shall be resolved through discussions between the ANL Peer Review Panel Chairman and the SRPO Deputy Project Manager. These discussions, along with 
QUALITY ASSURANCE PROGRAM

\section{ARGONNE PEER REVIEW ACTIVTTIES FOR THE SALT HOST-ROCK PORTION OF THE CIVILIAN RADIOACTIVE WASTE MANAGEMENT PROGRAM}

APPENDIX B: QAP-1, Design Control Procedures

Project No.: 23562

Page: 2 of 14

Issued: $8 / 12 / 86$

Revision: 0

the final approval or disapproval of the candidate, shall be documented for the project QA files. If an individual is not approved by SRPO, another individual shall be recommended for consideration, and the evaluation/approval process shall be repeated.

\section{B.3 SELECTION AND APPROVAL OF AUXILIARY PEER REVIEW PANELISTSS}

Potential auxiliary peer review panelists shall be identified by the Peer Review Panel Chairman and members of the core peer review group through authorship of technical publications, professional activities, recommendation by peers, professional reputation, and membership in key professional organizations. Each potential auxiliary panelist shall be telephoned to discuss the individual's research interests and experience, to determine whether he or she would be interested in serving on the ANL Peer Review Panel, to learn of the candidate's understanding of and involvement in the CRWM program, and to ascertain whether the candidate has a perceived or actual conflict of interest. A copy of each potential panelist's résumé shall be requested, and a written log of each conversation shall be made for future reference. The names of potential panelists shall be organized according to area of expertise, indicated interest in serving as a reviewer, indicated availability, indicated conflict of interest, and indicated previous experience with the radioactive waste isolation program. Specific experience with bedded or domed salt shall also be noted.

The initial group of auxiliary panelists and alternates was chosen by the ANL core group based on the information described above, the submitted résumés, and the results of the telephone conversations with the individuals. All résumés and supporting documentation were submitted to SRPO for consideration and evaluation. Initial SRPO concurrence with the selected panelists was made verbally; most selections were subsequently confirmed in letters from SRPO to the ANL Peer Review Panel Chairman. These letters are part of the project QA records. 
ARGONNE PEER REVIEW ACTIVITIES FOR THE SALT HOST-ROCK PORTION OF THE CIVILLAN RADIOACTIVE WASTE MANAGEMENT PROGRAM

Auxiliary panelists shall be added as needed. Individuals with appropriate experience and expertise shall be identified and contacted by members of the core group. Individuals shall be considered for nomination based on their record of research and their familiarity with the scientific or technical area or subject of concern; recommendations from SRPO, core group members, or other auxiliary panelists; discussions with individuals, as documented by telecons; and evaluations of résumés by appropriate members of the ANL core group. After initial screening by the core group, the credentials of a preferred individual shall be submitted with a letter to SRPO, nominating that individual as an auxiliary panelist. Following SRPO evaluation and concurrence, written approval for an individual to serve as an auxiliary panelist sinall be provided by SRPO and maintained in the project QA files.

Should SRPO not immediately approve a candidate auxiliary peer review panelist, the issue shall be resolved through discussions between the ANL Peer Review Panel Chairman and the SRPO Deputy Project Manager. Such discussions, along with final SRPO approval or disapproval of the candidate, shall be documented for the project QA files. If an individual is not approved, an alternate with appropriate expertise shall be identified and recommended to SRPO for consideration.

\section{B.4 PEER REVIEW PROCESS}

Figure B.1 is a flowchart of the ANL peer review process. Sixteen discrete steps occur between initiation and completion, which is marked by publication of an ANL report (technical memorandum) presenting the results of the peer review.

\section{B.4.1 SRPO Initiation of Peer Review Process}

The peer review process shall be initiated by transmittal of a review package from SRPO to ANL. This package shall consist of the document(s) to be reviewed, any support or documentation materials, and a letter of transmittal from the SRPO Deputy 


\section{ARGONNE PEER REVIEW ACTIVITIES FOR THE SALT HOST-ROCK PORTION OF THE CIVILLAN RADIOACTIVE WASTE MANAGEMENT PROGRAM}

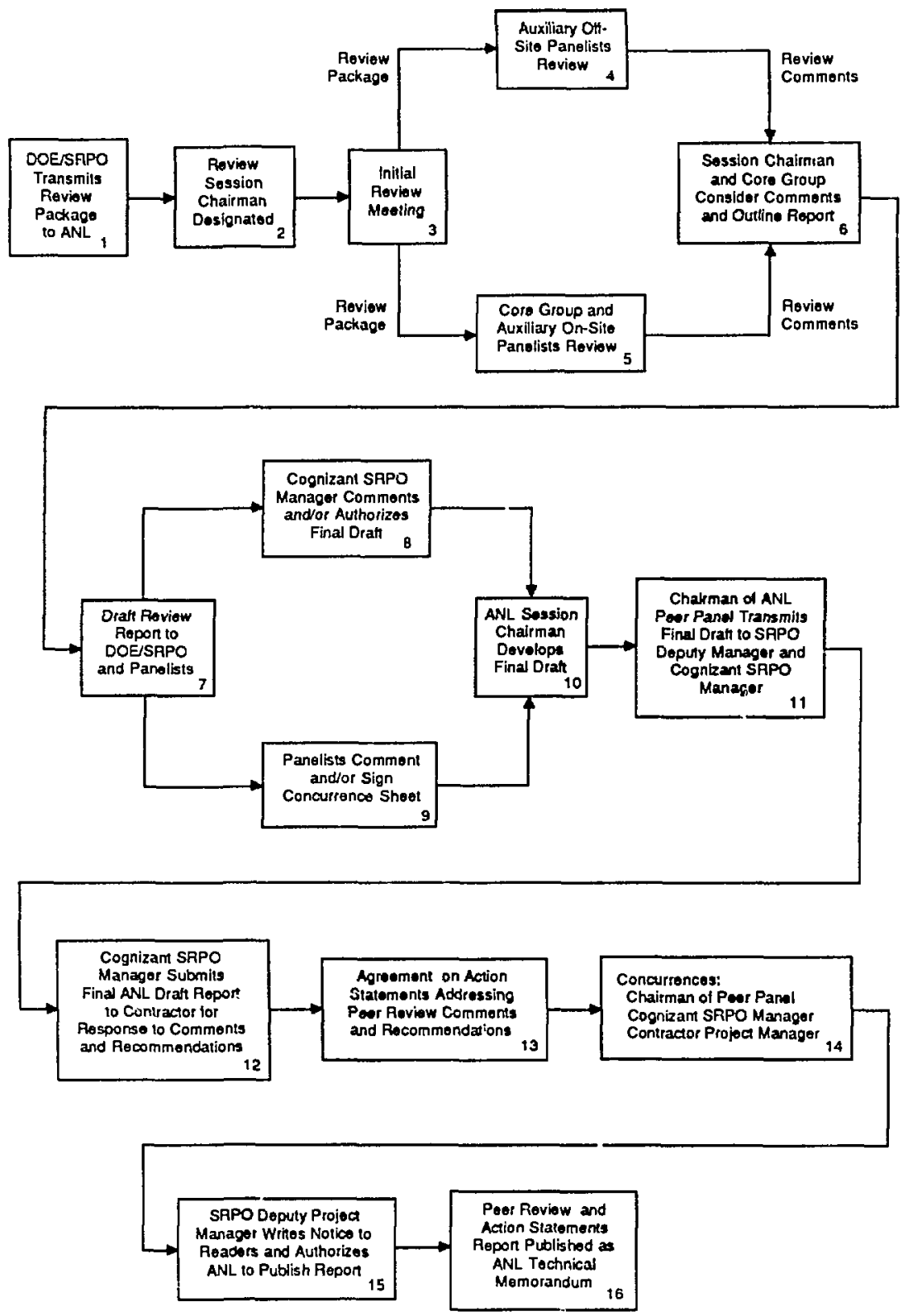

FIGURE B.1 Flowchart of the ANL Peer Review Prucess 
QUALITY ASSURANCE PROGRAM

ARGONNE PEER REVIEW ACTIVITIES FOR THE SALT HOST-ROCK PORTION

OF THE CIVILIAN RADIOACTIVE WASTE MANAGEMENT PROGRAM

APPENDIX B: QAP-1, Design Control Procedures

Project No.: 23562

Page: 5 of 14

Issued: $8 / 12 / 86$

Revision: 0

Project Manager to the ANL Peer Review Panel Chairman. The letter of transmittal shall identify the document(s) to be reviewed and state the date when the initial peer review results shall be forwarded to SRPO, and may provide general objectives and focus for the review.

\section{B.4.2 Designation of Review Session Chairman}

Upon receipt and examination of the review package, the Peer Review Panel Chairman shall designate a member of the ANL core peer review group to serve as Review Session Chairman for that particular peer review. Alternatively, the Peer Review Panel Chairman may elect to chair the session. Selection of the Review Session Chairman shall be made on the basis of the contents of the review package received from SRPO.

\section{B.4.3 Initial Peer Review Meeting}

The Peer Review Panel Chairman and the designated Review Session Chairman shall select appropriate core peer review group members to participate in the review. Each participant shall be provided with a copy of the review package for initial examination. The panel chairman, session chairman, and core group reviewers shall meet to identify appropriate auxiliary panelists, to evaluate and discuss the objectives or general guidance provided by SRPO in the transmittal letter, to develop an approach for that review, and to ccnsider any additional requirements and specific instructions for all reviewers that might be appropriate. The Review Session Chairman and the Peer Review Panel Chairman shall then prepare specific instructions for each review panelist that incorporate relevant guidance provided by SRPO and any additional requirements or instructions resulting from the initial review meeting. 


\section{QUALITY ASSURANCE PROGRAM \\ ARGONNE PEER REVIEW ACTIVTIES FOR THE SALT HOST-ROCK PORTION \\ OF THE CIVILIAN RADIOACTIVE WASTE MANAGEMENT PROGRAM}

APPENDIX B: QAP-1, Design Control Procedures

Project No.: 23562

Page: 6 of 14

Issued: $8 / 12 / 86$

Revision: 0

\section{B.4.4 Transmittal of Review Package to Auxiliary Off-Site Panelists}

Each auxiliary off-site review panelist selected for a given review shall be sent a package containing the material to be reviewed, any supporting documentation or reference material as may be required, and a letter of transmittal from the Peer Review Panel Chairman. This letter shall contain specific instructions and guidance to the reviewer and shall state the date by which his or her comments must be received at ANL.

\section{B.4.5 Transmittal of Review Package to Core Group and Auxiliary On-Site Panelists}

Each auxiliary on-site (ANL) review panelist selected for a given review shall be sent a package containing the material to be reviewed, any supporting documentation or reference material as may be required, and an ANL intra-laboratory memorandum from the Review Session Chairman. This memo shall contain specific instructions and guidance to the reviewer and shall state the date by which the reviewer's comments must be received by the Review Session Chairman. Each core group member selected for the review shall also receive a memo from the Review Session Chairman that provides specific instructions for the review and the date by which his or her comments must be provided to the Review Session Chairman.

\section{B.4.6 Consideration of Comments and Outlining of ANL Draft Review Report}

Written review comments shall be provided to the Peer Review Panel Chairman by all auxiliary off-site panelists and to the Review Session Chairman by on-site auxiliary panelists and core group reviewers. Photocopies of all comments, as received, shall be distributed to all core group reviewers and to any auxiliary panalists as necessary. The Review Session Chairman shall subsequently convene a meeting of the relevant core group reviewers, the Peer Review Panel Chairman, and any auxiliary peer panelists deemed necessary. During this meeting, all review comments shall be discussed, under the direction of the Review Session Chairman; the content of the ANL peer review report shall be developed; a general outline for the report shall be prepared; and preliminary conclusions and recommendations shall be drafted. 
In preparation for the review panel meeting, each attendee shall carefully examine the complete package of received comments, with special attention being given to those comments by auxiliary parielists having similar areas of expertise. Each attendee shall evaluate the appropriateness of the comments in terms of the instructions and guidance provided by the Peer Review Panel Chairman or Review Session Chairman and in terms of comments provided by other panelists. If these evaluations indicate that some comments are inappropriate or that comments provided by one panelist are in conflict with those of another panelist, these situations shall be noted and discussed during the review panel meeting.

Depending on the specific circumstances, several options can be exercised to resolve problems associated with conflicting or clearly inappropriate comments. In instances when elimination of inappropriate comments clearly would have no adverse effect on the utility or quality of the review, such comments shall be noted during the review meeting and, with the consensus of panelists in attendance, such comments shall be eliminated from further consideration. In situations when the comments of a particular auxiliary panelist are considered to be inappropriately phrased, but crucial to the review, that panelist shall be contacted by the Review Session Chairman or appropriate core group panelist to discuss the problem and to obtain a revised version. These revised comments shall be provided to the Review Session Chairman for inclusion in the draft review report.

If apparently conflicting comments received from different panelists cannot be resolved readily by the review panel at the meeting, the panelists in question shall be contacted by the Review Session Chairman or appropriate core group panelists for further discussion and resolution. Such resolution usually results in one of the panelists in question modifying or clarifying the original comment or requesting that the original comment be withdrawn. If resolution cannot be obtained, all comments shall be included in the draft report, with the conflict clearly noted. 


\section{QUALITY ASSURANCE PROGRAM \\ ARGONNE PEER REVIEW ACTIVITIES FOR THE SALT HOST-ROCK PORTION OF THE CIVILIAN RADIOACTIVE WASTE MANAGEMENT PROGRAM}

APPENDIX B: QAP-1, Design Control Procedures

Project No.: 23562

Page: 8 of 14

Issued: $8 / 12 / 86$

Revision: 0

All actions taken to resolve conflicting, inappropriate, or otherwise problematic comments shall be documented, and records of all actions and decisions shall be maintained in the project QA files.

\section{B.4.7 Preparation and Distribution of Draft ANL Peer Review Report}

Using all review comments provided by the peer review panelists and the working outline and detailed notes resulting from the review session meeting, the designated Review Session Chairman shall prepare a draft peer review report containing the results of the review and presenting the conclusions and recommendations of the Peer Review Panel. This draft report shall be submitted to the Peer Review Panel Chairman for examination and approval prior to transmittal to the SRPO Deputy Project Manager, the the cognizant SRPO staff manager for whom the review was performed, and each offsite (non-ANL) auxiliary panelist participating in the review. Copies of the draft review report sent by the Peer Review Panel Chairman to SRPO shall be accompanied by a letter of transmittal that includes the date by which all SRPO comments on the draft report should be returned to the Peer Review Panel Chairman. Copies of the draft report shall also be sent by the Peer Review Panel Chairman to off-site auxiliary panelists. These copies shall be accomparied by a concurrence sheet and a transmittal letter requesting that panelists read the draft review report to determine whether their comments have been fairly represented. Panelists shall be requested to sign the concurrence sheet and return it to the Peer Review Panel Chairman if they concur with the way their comments have been used or incorporated in the draft report. If they do not agree, they shall be requested to identify their concerns and to provide suggestions to tine panel chairman for resolution of any identified problems.

Copies of the draft review report shall also be transmitted by the Review Session Chairman to each core group panelist and to each on-site auxiliary panelist. An intralaboratory memo shall accompany each report, with instructions to each reviewer to determine whether the content of the report accurately reflects his or her comments. 
Reviewers shall be requested to sign the concurrence sheet, held by the Administrative Secretary for the ANL peer review group, if they agree with the manner in which their comments were treated. Reviewers shall be instructed to transmit their comments on the draft report to the Review Session Chairman via an intra-laboratory memo by an indicated date.

\section{B.4.8 SRPO Review of Draft ANL Review Report}

The SRPO Deputy Project Manager (SRPO Peer Review Project Manager) and the cognizant SRPO staff manager originally requesting the peer review shall both receive copies of the draft review report for evaluation. If no comments on the draft report are received from SRPO by the date indicated in the letter of transmittal, the Peer Review Panel Chairman shall contact the cognizant SRPO manager to verify that no comments will be fortheoming.

If comments are provided by SRPO, the Peer Review Panel Chairman shall forward them to the designated Review Session Chairman for consideration during preparation of the final peer review draft report.

\section{B.4.9 Review of the Draft ANL Peer Review Report by Panelists}

All core group and auxiliary panelists participating in $\varepsilon$ given review shall receive a copy of the draft peer review report for evaluation and comment. As noted in Sec. B.4.7, each panelist shall be requested to determine whether his or her comments were treated appropriately in the draft report. Panelists may also provide other comments for improvement of the draft report, as they deem appropriate. Comments from off-site auxiliary panelists shall be forwarded to the Review Session Chairman by the Peer Review Panel Chairmar, whereas all comments from on-site auxiliary and core group panelists shall be transmitted directly to the Review Session Chairman. 
QUALITY ASSURANCE PROGRAM

ARGONNE PEER REVIEW ACTIVITIES FOR THE SALT HOST-ROCK PORTION

OF THE CIVILIAN RADIOACTIVE WASTE MANAGEMENT PROGRAM

APPENDIX B: QAP-1, Design Control Procedures

Project No.: 23562

Page: 10 of 14

Issued: $8 / 12 / 86$

Revision: 0

If an off-site auxiliary panelist does not agree with the manner in which his or her comments were treated, that panelist may decline to sign the concurrence sheet until the indicated problem is resolved, or the panelist may return the signed concurrence sheet with a statement that his or her concurrence is contingent upon resolution of the problem. In most cases, the panelist is contacted by the Review Session Chairman, resolution is obtained, and the activities related to such occurrences and the resolution obtained are documented for the project QA files. The Review Session Chairman shall interact with on-site auxiliary and core group panelists in a like manner. If total agreement cannot be reached, the minority opinion comment shall be noted in the text of the ANL report as having been expressed by the named reviewer.

\section{B.4.10 Preparation of Final Draft Review Report}

The draft peer review report shall be revised into final draft form by the designated Review Session Chairman. During this revision, the chairman shall address all comments provided by SRP and the review panelists. The final draft peer review report shall be reviewed and appro'red by the Peer Review Panel Chairman before distribution.

\section{B.4.11 Transmittal of Final Draft Review Report to SRPO}

After the final draft peer review report has been prepared by the Review Session Chairman and approved by the Peer Review Panel Chairman, it shall be transmitted to SRPO. One copy shall be sent to the SRPO Deputy Project Manager and one to the cognizant SRPO staff manager for whom the review was performed. 


\section{QUALITY ASSURANCE PROGRAM \\ ARGONNE PEER REVIEW ACTIVITIES FOR THE SALT HOST-ROCK PORTION \\ OF THE CIVILIAN RADIOACTIVE WASTE MANAGEMENT PROGRAM}

APPENDIX B: QAP-1, Design Control Procedures
Project No.: 23562
Page: 11 of 14
Issued: $8 / 12 / 86$
Revision: 0

\section{B.14.12 Transmittal of Final Peer Review Draft Report to Contractor*}

Upon receipt of the final draft peer review report from the Peer Review Panel Chairman, the cognizant SRPO staff manager shall send a copy to the appropriate contractor personnel. Alternatively, a copy can be sent directly to the appropriate contractor personnel by ANL at the request of the cognizant SRPO manager. The contractor shall consider the final draft report and shall respond in writing to the Peer Review Panel's comments and recommendations. The contractor shall recommend actions that it believes should be taken to address the ANL comments and recommendations. This response shall be sent to the cognizant SRPO manager, who shall transmit a copy to the Peer Review Panel Chairman for consideration. Alternatively, the cognizant SRPO manager could request that the response be sent to ANL and SRPO simultaneously.

\section{B.4.13 Resolution of Aetion Statements in Response to the Review Comments}

The purpose of the response resolution phase of the peer review process is to obtain agreement on formal action statements corresponding to the comments and recommendations contained in the final draft peer review report. These action statements must be acceptable to ANL, SRPO, and the contractor, and shall be appended to the report before final publication by ANL.

The Peer Review Panel Chairman shall provide to the Review Session Chairman a copy of the contractor's written response to the final draft peer review report. These two individuals, after discretionary consultation with appropriate core and auxiliary panelists on selected responses, shall evaluate the contractor's recommended action statements to determine if they are appropriate and adequate in terms of the panel's original comments and recommendations. Differences, if any, between the panel's

\footnotetext{
*The term contractor refers to the entity that prepared the material under review.
} 


\section{QUALITY ASSURANCE PROGRAM \\ ARGONNE PEER REVIEW ACTIVITIES FOR THE SALT HOST-ROCE PORTION \\ OF THE CIVILIAN RADIOACTIVE WASTE MANAGEMENT PROGRAM}

APPENDIX B: QAP-1, Design Control Procedures

Project No.: 23562

Page: 12 of 14

Issued: $8 / 12 / 86$

Revision: 0

comments and recommendations and the contractor's proposed actions shall be noted. The Review Session Chairman shall then prepare a draft appendix to the review report describing his or her concept of the actions to be taken as a result of the panel's original comments and recommendations and the contractor's recommended action statements. The draft report appendix containing the ANL-proposed action statements shall be submitted to the contractor for response and to the cognizant SRPO manager for information.

If the contractor does not agree to the specific action statements drafted by the Review Session Chairman, the contractor shall submit revised action statements to ANL. A new draft based on the revised action statements shall be prepared by the Review Session Chairman and again submitted to the contractor, with a copy to the cognizant SRPO manager. This process shall be repeated until all parties agree to the resolutions (action statements) or until the SRPO manager decides that a meeting is necessary to reconcile the remaining differences.

If a meeting is deemed necessary, the time and place of the meeting shall be arranged by the SRPO manager, and an agenda and format for the meeting shall be prepared by the ANL Peer Review Panel Chairman. The meeting shall be attended by the cognizant SRPO manager or a designee, the Peer Review Panel Chairman and Review Session Chairman or their designees, and appropriate contractor personnel. Other individuals representing SRPO, ANL, or the contractor may also be present as needed. On the basis of the results of this meeting, the draft appendix containing action. statements that consider peer review comments and recommendations and the contractor responses thereto shall be modified as necessary by the Review Session Chairman so that all parties agree on the content.

If ANL finds all of the contractor's recommended actions to be adequate and appropriate, and if the SRPO manager and the contractor agree to the action statements as drafted by the Review Session Chairman, an appendix to the final review report is prepared containing those action statements. 
ARGONNE PEER REVIEW ACTIVITIES FOR THE SALT HOST-ROCE PORTION OF THE CIVILIAN RADIOACTIVE WASTE MANAGEMENT PROGRAM

APPENDIX B: QAF-1, Design Control Procedures

Project No.: 23562

Page: 13 of 14

Issued: $8 / 12 / 86$

Revision: 0

During the response resolution phase of the peer review process, it is possible that ANL may agree to modify an original comment or recommendation based on additional insight obtained during the resolution process. Such modifications shall be clearly noted in the final peer review report appendix containing the agreed-upon action statements.

If final resolution cannot be reached, the irreconcilable differences shall be noted in the QA records for the review and in the resolution appendix to the published ANL review report.

\section{B.4.14 Concurrence with the Action Statement Appendix}

A copy of the appendix containing the agreed-upon action statements shall be transmitted to the cognizant SRPO manager and to the contractor by the Peer Review Panel Chairman, along with a concurrence sheet already signed by the chairman. The SRPO manager and contractor representative shall be asked to sign the concurrence sheet if they agree that the content of the appendix accurately reflects the mutually agreed-upon action statements. The signed concurrence sheet shall then be returned to the chairman for inclusion in the review report. If either the SRPO manager or the contractor representative takes issue with the content of the appendix, the Peer Review Panel Chairman shall be contacted, the problem resolved, and a revised version of the appendix shall be distributed for concurrence.

\section{B.4.15 SRPO Authorization for Publication of the Final ANL Peer Review Report}

Following concurrence by all parties with the content of the action statement appendix, the review report is complete. The SRPO Deputy Project Manager shall prepare a "notice to readers" statement, which explains the basis for the review and the materials reviewed, and indicates the appendix in which the final action statements resulting from the ANL-concucted peer review are found. Receipt of the "notice to 
QUALITY ASSURANCE PROGRAM

ARGONNE PEER REVIEW ACTIVITIES FOR THE SALT HOST-ROCE PORTION

OF THE CIVILIAN RADIOACTIVE WASTE MANAGEMENT PROGRAM

APPENDIX B: QAP-1, Design Control Procedures

Project No.: 23562

Page: 14 of 14

Issued: $8 / 12 / 86$

Revision: 0

readers" statement by the Peer Review Panel Chairman shall constitute SRPO authorization for ANL to publish the final draft of the peer review report.

\section{B.4.16 Publication of the Final ANL Peer Review Report}

The final peer review report, which shall contain the SRPO "notice to readers," the detailed comments and recommendations of the peer review panel, the concurrence sheet signed by all reviewers, abbreviated résumés of all review panelists, the action statements resolution appendix based on the contractor responses to comments, and the signed concurrence sheet for the action statements resolution appendix, shall be published as an ANL technical memorandum. A microfiche copy of the reviewed material shall also be included in the ANL report.

Distribution of the published report completes the peer review process. Generally, 100 copies are published. Approximately 50 copies are needed for ANL's internal distribution list, for non-ANL authors, and for National Technical Information Service reference copy requirements. The remaining copies are forwarded to SRPO. 


\section{QUALITY ASSURANCE PROGRAM}

ARGONNE PEER REVIEW ACTIVITIES FOR THE SALT HOST-ROCK PORTION

OF THE CIVLLIAN RADIOACTIVE WASTE MANAGEMENT PROGRAM

\section{APPENDIX C}

QAP-2, Document Control Procedures 


\section{QUALITY ASSURANCE PROGRAM \\ ARGONNE PEER REVIEW ACTIVITIES FOR THE SALT HOST-ROCK PORTION OF THE CIVILIAN RADIOACTIVE WASTE MANAGEMENT PROGRAM}

\begin{abstract}
APPENDIX C: QAP-2, Document
Control Procedures
\end{abstract}

Project No.: 23562

Page: 1 of 4

Issued: $8 / 12 / 86$

Revision: 0

\section{C.1 GENERAL}

Appendix $\mathrm{C}$ presents the procedures for controlling the preparation, issue, and revision of documents that specify quality requirements or prescribe activities that affect quality, to assure that correct and up-to-date documents are being used.

\section{C.2 DOCUMENT CONTROL PROCEDURES}

Controlled documents that specify quality requirements or activities affecting quality shall be prepared by the project QA Coordinator, reviewed by EES's QAR and ANL's QASO, and approved by the Peer Review Panel Chairman. All copies of controlled documents that specify quality requirements or that prescribe activities affecting the quality of the peer review process and its products shall be assigned a unique controlled copy number.

One copy of all controlled documents shall be issued to each core peer review panelist and to each of the following individuals or orjanizational entities: SRPO QA Department, ANL QASO, EES QAR, peer review Administrative Secretary, and peer review project QA Coordinator. Additional copies shall be issued to interested parties upon request.

Unissued copies of controlled documents shall be kept in the peer review project QA files, together with dorument log forms that list the following information:

- Document and section name, revision number, and issue date.

- Number of copies produced.

- Contrulled copy number, recipient, date sent, individual sending copy, date of receipt, and individual confirming receipt for all distributed copies. 
APPENDIX C: QAP-2, Document

Control Procedures
Project No.: 23562

Page: 2 of 4

Issued: $8 / 12 / 86$

Revision: 0

At the time of its original issue, each controlled document copy shall be accompanied by a document transmittal form that shall be signed by the recipient to acknowledge receipt and returned to the Administrative Secretary. Signed and returned transmittal forms shall be kept in the project QA files.

At the time the revised material is issued, the material shall be accompanied by a document transmittal form that advises that the superseded pages are to be removed from the controlled document and returned to the Administrative Secretary. An updated and revised revision control sheet and a replacement signature sheet shall be transmitted with each revision of any portion of the QA Program. The transmittal sheet shall be signed by the recipient to acknowledge receipt of the material and returned to the Administrative Secretary. Signed and returned transmittal forms shall be kept in the project QA files.

\section{C.3 DOCUMENTATION}

Figure C.1 shows the document $\log$ form, and Fig. C.2 shows the document transmittal form (Sec. C.2). 
APPENDIX C: QAP-2, Document

Control Procedures
Project No.: 23562

Page: 3 of 4

Issued: $8 / 12 / 86$

Revision: 0

DOCUMENT CONTROL LOG

ARGONNE PEER REVIEW ACTIVITIES FOR

THE SALT HOST-ROCK PORTION OF THE

CIVILIAN RADIOACTIVE WASTE MANAGEMENT PROGRAM

Document Name

Number of Copies Revision No.

Issue Date

\begin{tabular}{|c|c|c|c|c|c|}
\hline $\begin{array}{l}\text { COPY } \\
\text { NO. }\end{array}$ & ISSUED TO & $\begin{array}{l}\text { DATE } \\
\text { SENT }\end{array}$ & $\begin{array}{l}\text { SENT } \\
\text { EY }\end{array}$ & $\begin{array}{c}\text { DATE } \\
\text { RECEIVED }\end{array}$ & $\begin{array}{c}\text { CONFIRMED } \\
\text { BY }\end{array}$ \\
\hline & & & & & $\xi$ \\
\hline & & & & & $\vdots$ \\
\hline & & & & & \\
\hline & & & & & \\
\hline & & & & & \\
\hline & & & & & \\
\hline & & & & & \\
\hline & & & & & \\
\hline & & & & & \\
\hline & & & & & \\
\hline & & & & & \\
\hline & & & & & \\
\hline & & & & & \\
\hline & & & & & \\
\hline & & & & & \\
\hline & & & & & \\
\hline & & & & & \\
\hline & & & & & \\
\hline & & & & & \\
\hline
\end{tabular}

FIGURE C.1 Document Control Log Form 

of

ARGONNE PEER REVIEW ACTIVITIES FOR

THE SALT HOST-ROCK PORTION OF

THE CIVILIAN RADIOACTIVE WASTE MANAGEMENT PROGRAM

\begin{tabular}{|l|l|}
\hline To: & From: \\
\hline (Name) & ARGONNE NATIONAL LABORATORY \\
& EES-362 \\
(Organization) & A700 South Cass Avenue \\
& Argonne, IL 60439 \\
\hline
\end{tabular}

\begin{tabular}{|l|l|l|l|}
\hline DOCUMENT DESCRIPTION & REV. & DATE & $\begin{array}{c}\text { COPY } \\
\text { NO. }\end{array}$ \\
\hline & & & \\
\hline & & & \\
\hline & & & \\
\hline & & & \\
\hline & & & \\
\hline
\end{tabular}

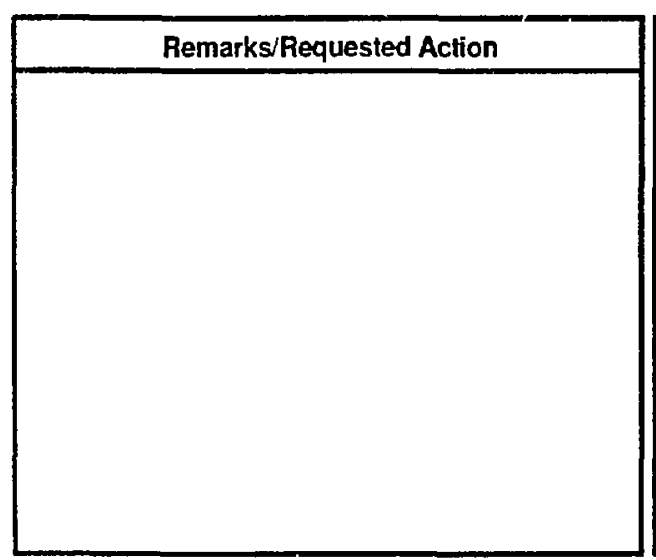

\begin{tabular}{|l|}
\hline \multicolumn{1}{|c|}{ Return Original to Sender } \\
\hline I hereby acknowledge receipt of the \\
documents transmitted to me by this form. \\
I also acknowledge that I have performed \\
the actions requested on this form. \\
(Signature) \\
\hline (Date)
\end{tabular}




\section{QUALITY ASSURANCE PROGRAM}

ARGONNE PEER REVIEW ACTIVITIES FOR THE SALT HOST-ROCK PORTION OF THE CIVILIAN RADIOACTIVE WASTE MANAGEMENT PROGRAM

APPENDIX D

QAP-3, Inspection Procedures 
ARGONNE PEER REVIEW ACTIVITIES FOR THE SALT HOST-ROCK PORTION

OF THE CIVILIAN RADIOACTIVE WASTE MANAGEMENT PROGRAM

APPENDIX D: QAP-3, Inspection Procedures

Project No.: 23562

Page: 1 of 2

Issued: $8 / 12 / 86$

Revision: 0

\section{D.1 GENERAL}

Inspections to verify that peer review activities have been accomplished in accordance with the procedures of ANL's QA Program shall be scheduled, performed, and documented at least once every six months. At a minimum, an inspection shall be performed just prior to distributing the final peer review draft report and again just prior to publishing the final report, which includes documentation of the response resolution process, to ensure that appropriate procedures were followed and documented and that all review comments and recommendations were accounted for.

\section{D.2 INSPECTION PROCEDURE}

The EES QAR shall plan and perform the required inspections. The project QA Coordinator shall advise the EES QAR of the status of peer reviews in progress and assist him or her in the preparation of an inspection checklist. The checklist shall be reviewed by the QASO QE prior to the inspection. Inspections shall cover all peer review activities up to the issuance of the final peer review draft report or the publication of the final draft report, or the period since the last inspection, whichever is applicable.

Inspections shall verify that the documentation required by this and other procedures of the QA Program has been prepared, received, identified, reviewed, approved, and/or retained in accordance with appropriate procedure. Follow-up verification of any corrective actions from previous inspections, if any, shall be included.

\section{D.3 DOCUMENTATION AND REPORTING}

Upon completion of the inspection, the EES QAR shall generate and issue a memorandum of inspection addressed to the Peer Review Panel Chairman. Copies shall be sent to the SRPO Project Manager, the SRPO QA Manager, the project QA Coordinator, and the ANL QASO QE. 


\section{QUALITY ASSURANCE PROGRAM \\ ARGONNE PEER REVIEW ACTIVITIES FOR THE SALT HOST-ROCK PORTION \\ OF THE CIVIIIAN RADIOACTIVE WASTE MANAGEMENT PROGRAM}

APPENDIX D: QAP-3, Inspection Procedures
Project No.: 23562
Page: 2 of 2
Issued: $8 / 12 / 86$
Revision: 0

The memorandum of inspection shall identify the items inspected and the results obtained. Nonconformances shall be identified in the memorandum. Processing and documenting the disposition of nonconformances, as well as documenting and verifying corrective actions, are addressed in App. E.

\section{D.4 RETENTION OF INSPECTION DOCUMENTS}

Memoranda of inspection and related documentation, such as that relating to disposition of nonconformances and implementation of corrective actions, shall be retained in accordance with App. F. 


\section{QUALITY ASSURANCE PROGRAM}

\section{ARGONNE PEER REVIEW ACTIVTIES FOR THE SALT HOST-ROCK PORTION OF THE CIVILLAN RADIOACTIVE WASTE MANAGEMENT PROGRAM}

\section{APPENDIX E}

QAP-4, Control of Nonconforming Items and Corrective Action Procedures 
APPENDIX E: QAP-4, Control of Nonconforming Items and Corrective Action Procedures
Project No.: 23562

Page: 1 of 3

Issued: $8 / 12 / 86$

Revision: 0

\section{E.1 GENERAL}

Appendix E presents the procedures for identifying, documenting, evaluating, and disposing of nonconformances and nonconforming items and for identifying and implementing corrective actions.

\section{E.2 DEFINITIONS}

As defined in Sec. 15.3, a nonconformance is a deficiency in characteristic, documentation, or procedure that renders the quality of an item or activity unacceptable or indeterminate. A nonconforming item could be any documentation or record of some phase of a specific review or other project activity that contains or is associated with an identified nonconformance. However, for this project, a nonconforming item is a published peer review report identified as containing errors or omissions of such significance that the content of the report is questionable or clearly deficient.

\section{E.3 PROCEDURES FOR CONTROL OF NONCONFORMANCES}

\section{E.3.1 Nonconformances Detected during Inspections}

Inspections shall be scheduled and performed (Sec. 10.0 and App. D) to verify that adequate management systems are in place to assure that procedures affecting quality are appropriate and properly implemented. Inspections also provide a check to determine whether approved procedures are followed consistently. All nonconformances identified as a result of inspection activities shall be documented in a memorandum of inspection and in a nonconformance report. 


\section{QUALITY ASSURANCE PROGRAM \\ ARGONNE PEER REVIEW ACTIVITIES FOR THE SALT HOST-ROCK PORTION \\ OF THE CIVILIAN RADIOACTIVE WASTE MANAGEMENT PROGRAM}

APPENDIX E: QAP-4, Control of Nonconforming Items and Corrective Action Procedures
Project No.: 23562

Page: 2 of 3

Issued: $8 / 12 / 86$

Revision: 0

\section{E.3.2 Miscellaneous Nonconformances}

All personnel involved in the peer review task shall be responsible for reporting all suspected nonconformances encountered during the performance of project activities. All suspect conditions or occurrences shall be reported to the project QA Coordinator for evaluation. The QA Coordinator shall document this evaluation, and, if a nonconformance is identified and confirmed, prepare a nonconformance report.

\section{E.3.3 Disposition of Nonconformances}

The disposition of nonconformances that cannot be corrected so as to be in conformance with the QA Program shall be approved by the Peer Review Panel Chairman.

\section{E.4 CORRECTIVE ACTION FOR NONCONFORMANCES}

In addition to describing the identified nonconformance, each nonconformance report shall describe the corrective action taken to remedy the nonconformance and to prevent a recurrence. Corrective actions shall be taken as prescribed by the Review Session Chairman, with the concurrence of the QA Coordinator. The QA Coordinator shall verify that the corrective action is implemented in a timely manner and shall document completion of the action.

\section{E.5 PROCEDURES FOR CONTROL OF NONCONFORMING ITEMS}

As noted in Sec. E.2, nonconforming items refer to published peer review reports identified as containing significant errors or omissions. Inspections shall be conducted immediately prior to publication of final peer review reports to minimize nonconforming items. Should a significant error or omission be identified after publication of a final draft report, this situation shall be documented in a nonconformance report, and corrective action shall be prescribed by the Peer Review Panel Chairman. 
ARGONNE PEER REVIEW ACTIVITIES FOR THE SALT HOST-ROCK PORTION

OF THE CIVILIAN RADIOACTIVE WASTE MANAGEMENT PROGRAM

APPENDIX E: QAP-4, Control of Nonconforming Items and Corrective Action Procedures
Project No.: 23562

Page: 3 of 3

Issued: $8 / 12 / 86$

Revision: 0

\section{E.6 CORRECTIVE ACTION FOR NONCONFORMING ITEMS}

The standard corrective action for nonconforming items as defined above shall be preparation and distribution of an erratum sheet. This sheet shall clearly identify all errors or omissions in the published peer review report and contain the corrected or added information necessary to remedy the error or omission. The erratum sheet shall be prepared by the Review Session Chairman and reviewed by the Review Panel Chairman and QA Coordinator for adequacy before distribution.

All individuals and organizations on the distribution list for the final peer review report shall receive a copy of the erratum sheet. The distribution process shall be performed by the Administrative Secretary and verified by the QA Coordinator.

\section{E.7 RECORDS OF NONCONFORMANCES, NONCONFORMING ITEMS, AND CORRECTIVE ACTIONS}

The occurrence of nonconformances, nonconforming items, or other conditions adverse to quality shall be identified and described in nonconformance reports. All corrective actions prescribed to remedy nonconformances and nonconforming items and to preclude repetition of conditions adverse to quality shall also be fully described in nonconformance reports. Necessary follow-up actions to verify that the corrective action is appropriate, implemented, and closed out in a timely manner shall be documented and reported.

All nonconformance reports shall be distributed by the project QA Coordinator to the Peer Review Panel Chairman, the EES QAR, the QASO QE, the SRPO Project Manager, and the SRPO QA Manager. Copies of all nonconformance reports and documentation of all activities involving the control of nonconformances and nonconforming items, as well as associated corrective actions, shall be maintained in the project QA files. 


\section{QUALITY ASSURANCE PROGRAM}

2 ZGONNE PEER REVIEW ACTIVITIES FOR THE SALT HOST-ROCK PORTION OF THE CIVILIAN RADIOACTIVE WASTE MANAGEMENT PROGRAM

\section{APPENDIX F}

QAP-5, Quality Assurance Records Procedures 


\section{F.1 GENERAL}

A QA record is a document or item that furnishes evidence of the quality of items or activities affecting quality. Two general types of QA records shall be generated and maintained for the ANL peer review task: those documenting specific activities related to the peer review process and those pertaining to QA policies, procedures, and activities associated with the peer review task. Appendix $F$ describes the types of documents and items to be maintained in the peer review project QA files and how they are to be identified for storage and retrieval. It also presents information on procedures for access, control, and storage of project records, and elaborates on the related procedural requirements identified in Sec. 17. Although other records of project activities may be maintained for information and use by ANL staff, the records and procedures described in this appendix shall be maintained specifically for QA purposes, with the intent of satisfying the QA specification provided to ANL by SRPO.

\section{F.2 PROJECT RECORDS LIST}

Figure F.1 identifies the types of records to be maintained in the peer review project QA files. Updated versions of this project records list shall be prepared by the QA Coordinator, approved by the ANL Peer Review Panel Chairman, and transmitted for review and acceptance to the SRPO Project Manager and QA Manager.

\section{F.3 PROJECT RECORDS DESCRIPTIONS}

The two types of $Q A$ records noted above constitute the project files maintained for QA purposes. To facilitate organization, all project records shall be considered to be either incoming or outgoing. Incoming records are those documents or items providing information and input to peer review activities. They could be materials coming to ANL from outside sources (e.g., a review package to ANL from SRPO or review comments to the Peer Review Panel Chairman from off-site auxiliary panelists), or they could be materials originating within ANL but providing input to the review process (e.g., review comments to the Review Session Chairman from core group reviewers or a memorandum 


\section{ARGONNE PEER REVIEW ACTIVITIES FOR THE SALT HOST-ROCE PORTION} OF THE CIVILIAN RADIOACTIVE WASTE MANAGEMENT PROGRAM

APPENDIX F: QAP-5, QA Records Procedures

Project No.: 23562

Page: 2 of 15

Issued: $8 / 12 / 86$

Revision: 0

\begin{tabular}{|ll|}
\hline - Project QA Plan & - Nonconformance Memoranda \\
- Project QA Procedures & - Corrective Action Memoranda \\
- Personnel Qualifications & - Document Control Records \\
- Personnel Training & - Correspondence \\
- Project File Index Lists & - Instructions \\
- Audit Reports & - Review Activity Documentation \\
- Inspection Memoranda & - Peer Review Reports \\
- Unusual Occurrence Reports & - Procurement Records \\
\hline
\end{tabular}

FIGURE F.1 Project Records List for the ANL Peer Review Task

to file from the Peer Review Panel Chairman, designating the Review Session Chairman for a particular review). Outgoing records are those documents or items requesting input to the review process (e.g., a review package, including a request for review and instructions, to all panelists) or those providing information or the results of a particular review activity (e.g., a draft peer review report to SRPO). Section F.4 proviłes details concerning records identification, the organizational and storage/retrieval system, and QA records facilities.

\section{F.3.1 Documentation of QA Activities}

Quality assurance activities related to the peer review task can be grouped into four general categories. The first category includes activities completed at the project level; such activities primarily involve project personnel only. Examples of activities of this type are personnel QA indoctrination sessions, surveillance and inspection actions, distribution of controlled documents, and maintenance and implementation of the peer review task QA Program. Records of these activities shall be maintained in the form of file memoranda, inspection and surveillance memoranda or reports, nonconformance memoranda, the peer review task QA Program, and similar documents. 


\section{QUALITY ASSURANCE PROGRAM \\ ARGONNE PEER REVIEW ACTIVITIES FOR THE SAIT HOST-ROCK PORTION \\ OF THE CIVILLAN RADIOACTIVE WASTE MANAGEMENT PROGRAM}

APPENDIX F: QAP-5, QA Records Procedures

Project No.: 23562

Page: 3 of 15

Issued: $8 / 12 / 86$

Revision: 0

The second category includes activities performed principally at the ANL division level. Thus, all activities and actions undertaken by the EES QA Committee and the EES QAR fall into this category, and records of these activities might include committee meeting notes or minutes, memoranda from the EES QAR regarding divisional QA policies and procedures, and similar documentation.

The third category requiring documentation is QA activities related to ANL QA policies, procedures, and actions involving ANL QA and management staff. The ANL Quality Assurance Policy and Procedures Manual, together with memoranda or other documentation of the ANL QA organization and program having a bearing on the QA activities for the peer review task, shall be maintained in the project records system.

The fourth category of QA documentation is records pertaining to DOE and SRPO QA policies, procedures, and actions. Such documentation includes manuals, orders, written procedures, project QA specifications, correspondence on QA matters, and any related records that document procedures, activities, or requirements affecting peer review activities.

Most records of $\mathrm{QA}$ activities for the peer review task belong to the first category. However, records falling within the remaining categories shall be identified and entered into the records system, provided that they relate to or affect ongoing project QA efforts. In addition to the types of records or documents identified above, other documentation shall be incorporated into the project records system as necessary to fully document peer review project QA activities, procedures, and requirements.

\section{F.3.2 Peer Review Process Documentation}

As discussed in App. B and Sec. 3, the peer review process comprises sequential steps, beginning with receipt of a review package from SRPO and concluding with publication and distribution of an ANL report presenting the results of a particular review. As shown in Fig. F.2, each step shall be documented in some form, and that documentation shall become part of the project QA records system. 


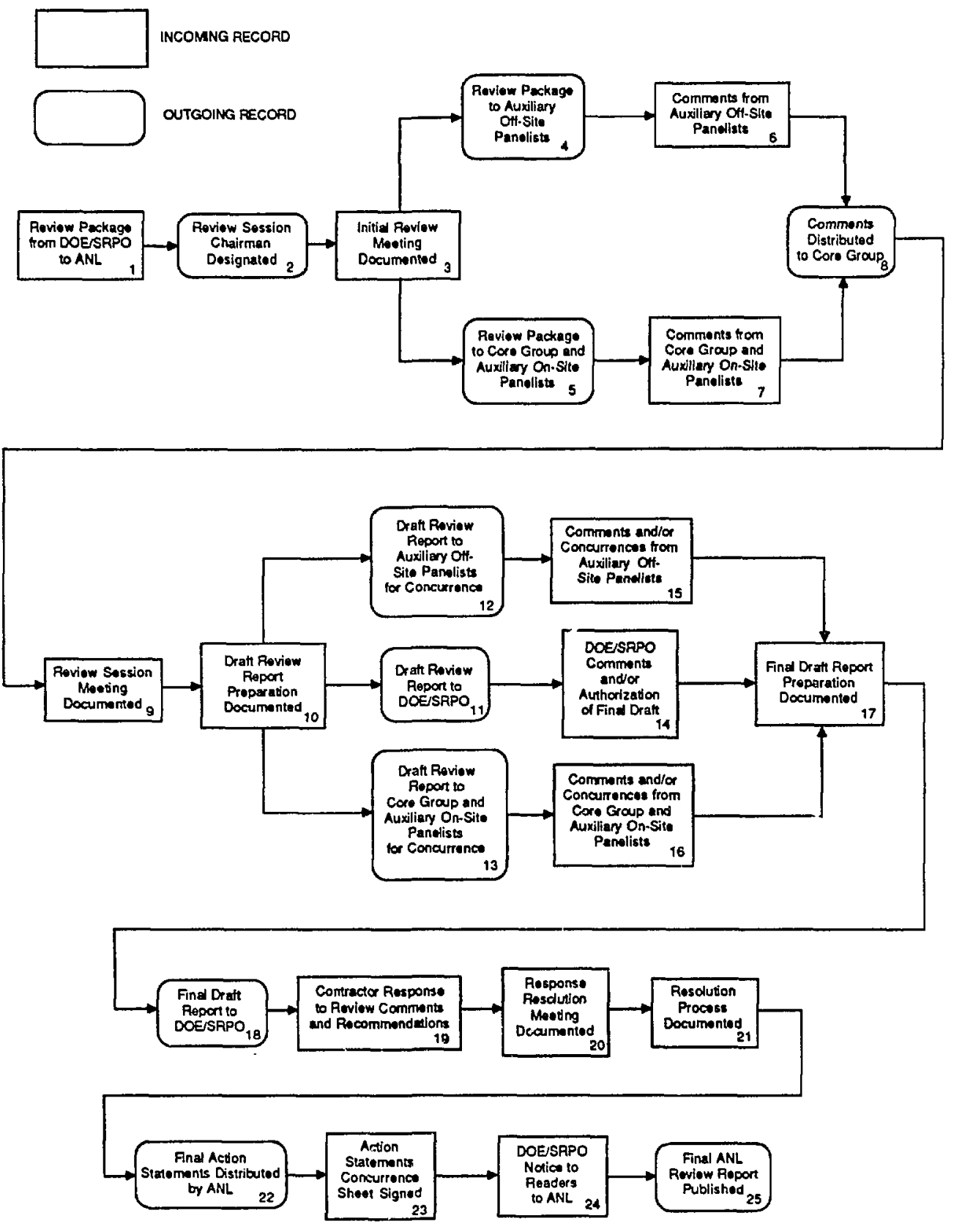

FIGURE F.2 QA Documentation of the ANL Peer Review Process 


\section{QUALITY ASSURANCE PROGRAM \\ ARGONNE PEER REVIEW ACTIVITIES FOR THE SALT HOST-ROCK PORTION OF THE CIVILIAN RADIOACTIVE WASTE MANAGEMENT PROGRAM}

APPENDIX F: QAP-5, QA Records Procedures

Project No.: 23562

Page: 5 of 15

Issued: $8 / 12 / 86$

Revision: 0

In the following sections, each of the steps in Fig. F.2 is briefly described. In each instance, a QA code and number, along with the appropriate file location number, shall be assigned by the Administrative Secretary. These identification numbers shall be placed on the item, and appropriate entries shall be made on the records log and index as described in Sec. F.4. For brevity, these actions are not repeated in the following descriptions.

\section{F.3.2.1 Review Package Received from SRPO}

The peer review process begins when SRPO sends ANL the material to be reviewed, along with a letter requesting the review. This letter may also provide general guidance as to the emphasis of the review or questions that the review panel should consider. Upon receipt, this package (i.e., letter, material for review, and any supporting materials) shall be entered into the records system and the originals placed as received in the project QA files.

\section{F.3.2.2 Review Session Chairman Designated}

The Peer Review Panel Chairman shall designate an individual, usually a member of the core peer review group, to chair the review session for the material received. This designation shall be documented by a memorandum to file prepared by the Peer Review Panel Chairman.

\section{F.3.2.3 Initial Review Meeting Results}

An initial review meeting shall be held by the Peer Review Panel Chairman and the Review Session Chairman, and other core panelists if desired, to determine which auxiliary panelists to use for the review and to formulate the details of the review approach, including the drafting of specific instructions for each review panelist. The results of this meeting shall be summarized and documented in a memorandum to file. 
ARGONNE PEER REVIEW ACTIVITIES FOR THE SALT HOST-ROCK PORTION

OF THE CIVILIAN RADIOACTIVE WASTE MANAGEMENT PROGRAM

APPENDIX F: QAP-5, QA Records Procedures

Project No.: 23562

Page: 6 of 15

Issued: $8 / 12 / 86$

Revision: 0

\section{F.3.2.4 Review Package Forwarded to Off-Site Panelists}

The review package, which contains the material to be reviewed, any necessary supporting material, and instructions, shall be sent to each of f-site panelist by the Peer Review Panel Chairman. A copy of each transmittal letter shall become part of the QA records, but only one set of enclosures shall be filed. Notes attached to the remaining letters shall indicate the location of the copy of the enclosures.

\section{F.3.2.5 Review Package Forwarded to On-Site Panelists}

The review package shall be sent to each on-site panelist under cover of a memorandum from the Review Session Chairman. A copy of each memo shall be entered into the QA records system, along with a note referencing the location of the file copy of the review package.

\section{F.3.2.6 Comments Received from Off-Site Panelists}

As comments are received from off-site panelists, they shall be forwarded to the Administrative Secretary for logging into the records system and filing. After all comments are received, copies shall be made for each panelist participating in the review session meeting; original comments shall be retained as received in the files.

\section{F.3.2.7 Comments Received from On-Site Panelists}

Comments provided by on-site panelists shall be processed in the same manner as those from off-site panelists (Sec. F.3.2.6).

\section{F.3.2.8 Comments Distributed to Core Peer Review Group}

Copies of all comments received shall be distributed by the Review Session Chairman to each member of the core peer review group participating in the review. Copies of all memoranda of transmittal and one copy of the comments as distributed 
QUALITY ASSURANCE PROGRAM

ARGONNE PEER REVIEW ACTIVITIES FOR THE SALT HOST-ROCK PORTION

OF THE CIVLLAN RADIOACTIVE WASTE MANAGEMENT PROGRAM

APPENDIX F: QAP-5, QA Records Procedures

Project No.: 23562

Page: 7 of 15

Issued: $8 / 12 / 86$

Revision: 0

shall be entered into the records system. As in Sec. F.3.2.4, all memoranda shall be cross-referenced to the location of the file copy of the comments package. In the event that off-site panelists participate in the review session meeting, comments shall be provided to them by the Peer Review Panel Chairman, and copies of the letters of transmittal shall be entered into the records system in the same manner.

\section{F.3.2.9 Documentation of Review Session Meeting Results}

The results of the review session meeting shall be documented in a memorandum to file.

\section{F.3.2.10 Dosumentation of Draft Peer Review Report Preparation}

The Review Session Chairman shall prepare a memorandum to file that summarizes all activities performed during preparation of the draft peer review report. In particular, actions taken that restit in a change in comments from those received or that resuit in comments not being included in the draft report shall be documented, along with the reasons for such action. All notes, records of telephone conversations, and related supporting materials shall be appended to this memorandum and entered as part of the project QA records.

\section{F.3.2.11 Draft Review Report Transmitted to SRPO}

Copies of all letters that transmit copies of the draft peer review report to SRPO shall be entered into the records system, along with one copy of the report. File copies of letters without the report shall be cross-referenced to its location.

\section{F.3.2.12 Draft Review Report Sent to Off-Site Panelists}

A copy of the draft peer review report shall be sent by the Peer Review Panel Chairman to each off-site panelist, along with a concurrence sheet and instructions to 
ARGONNE PEER REVIEW ACTIVITIES FOR THE SALT HOST-ROCK PORTION

OF THE CIVILIAN RADIOACTIVE WASTE MANAGEMENT PROGRAM

APPENDIX F: QAP-5, QA Records Procedures

Project No.: 23562

Page: 8 of 15

Issued: $8 / 12 / 86$

Revision: 0

sign the sheet if that reviewer concurs with the manner in which his or her comments are treated in the report. Copies of all transmittal letters shall become QA records, and each shall be cross-referenced to the file location of the copy of the draft report.

\section{F.3.2.13 Draft Review Report Sent to On-Site Panelists}

The draft peer review report shall be sent to each on-site panelist by the Review Session Chairman. Reviewers shall be requested to sign the concurrence sheet held by the Administrative Secretary if they agree with the treatment of their comments in the report. A copy of each memorandum of transmittal shall be entered into the QA records system and cross-referenced to the file location of the draft report.

\section{F.3.2.14 Comments and/or Authorization of Final Draft Report from SRPO}

Any comments provided by SRPO and/or an authorization to proceed with preparation of the final peer review draft report shall be entered into the QA records system upon receipt. If no somments or authorization is received by the date specified in the transmittal letter, the Peer Review Panel Chairman shall contact the appropriate manager at SRPO for approval to proceed. A record of this telephone conversation shall be entered into the $\mathrm{QA}$ records system.

\section{F.3.2.15 Comments and/or Concurrences Received from Off-Site Panelists}

All comments and signed concurrence sheets shall be entered into the QA records system upon receipt at ANL. Comments shall be copied and transmitted to the Review Session Chairman.

\section{F.3.2.16 Comments and/or Coneurrences Received from On-Site Panelists}

All comments received shall become a part of the QA records, as does the concurrence sheet signed by on-site panelists. Comments shall be copied and transmitted to the Review Session Chairman. 


\section{QUALITY ASSURANCE PROGRAM \\ ARGONNE PEER REVIEW ACTIVITIES FOR THE SALT HOST-ROCE PORTION \\ OF THE CIVLLAN RADIOACTIVE WASTE MANAGEMENT PROGRAM}

APPENDIX F: QAP-5, QA Records Procedures
Project No.: 23562
Page: 9 of 15
Issued: $8 / 12 / 86$
Revision: 0

\section{F.3.2.17 Documentation of Final Peer Review Draft Report Preparation}

The Review Session Chairman shall prepare a memorandum to file that summarizes the major actions performed during preparation of the final draft peer review report. Documentation of actions, as appropriate, shall be appended to the memorandum and entered in to the QA records system.

\section{F.3.2.18 Final Draft Peer Review Report Transmitted to SRPO}

One copy of the final peer review draft report and each transmittal letter to SRPO shall be filed in the QA records system.

\section{F.3.2.19 Contractor Response to Review Comments}

Upon receipt by ANL, the contractor's response to the peer review comments and recommendations contained in the final draft peer review report shall be entered into the QA records system, and the original shall be filed. Copies shall be provided to the Review Session Chairman and Peer Review Panel Chairman for evaluation.

\section{F.3.2.20 Results of Response Resolution Meeting}

If a meeting between representatives of SRPO, ANL, and the contractor is required to resolve discrepancies between the peer review comments and recommendations and the actions proposed by the contractor in response to those comments and recommendations, the results of that meeting shall be fully documented and entered into the QA records system.

\section{F.3.2.21 Documentation of the Resolution Process}

As described in App. B, the process necessary for representatives of ANL, SRPO, and the contractor to reach agreement on actions to be taken in response to the peer review comments and recommendations is usually iterative and may be relatively 
QUALITY ASSURANCE PROGRAM

ARGONNE PEER REVIEW ACTIVITIES FOR THE SALT HOST-ROCK PORTION

OF THE CIVILIAN RADIOACTIVE WASTE MANAGEMENT PROGRAM

APPENDIX F: QAP-5, QA Records Procedures

Project No.: $\mathbf{2 3 5 6 2}$

Page: 10 of 15

Issued: $8 / 12 / 86$

Revision: 0

complex. The Review Session Chairman shall prepare a memorandum to file describing the major steps and actions performed during the resolution process. Documentation of actions shall be appended to this memorandum, as appropriate, for inclusion in the QA records system and files.

\section{F.3.2.22 Final Action Statements Distributed by ANL}

Final action statements in response to ANL recommendations and comments shall appear in an appendix to the final peer review report. The final action statements, as distributed, shall be in the anticipated final form, that is, as they will appear in the appendix to the published report. A copy of this appendix and all letters of transmittal shall be entered into the records system.

\section{F.3.2.23 Action Statements Concurrence Sheet Signed}

If the appendix containing the action statements as distributed is agreeable to all parties, the Peer Review Panel Chairman, the cognizant SRPO manager, and the designated contractor representative or their designees shall sign the concurrence sheet. The signed concurrence sheet shall be placed in the QA records system and file.

\section{F.3.2.24 SRPO Provides "Notice to Readers" Statement}

The "notice to readers" statement shall be provided to ANL by SRPO for inclusion in the published final peer review report. This notice shall describe SRPO's authorization of the review and may refer to some of the general SRPO guidance given or to the results of the review. The notice shall be signed by the SRPO Deputy Director and shall be entered into the $Q A$ records system upon receipt. 
ARGONNE PEER REVIEW ACTIVITIES FOR THE SALT HOST-ROCK POKTION OF THE CIVILIAN RADIOACTIVE WASTE MANAGEMENT PROGRAM

\section{APPENDIX F: QAP-5, QA Records Procedures}

Project No.: 23562

Page: 11 of 15

Issued: $8 / 12 / 86$

Revision: 0

\section{F.3.2.25 Final ANL Report Published}

One copy of the published final peer review report shall be placed in the QA records files. A copy of the letter transmitting copies of the final report to SRPO shall also be entered into the records system.

\section{F.4 PROJECT RECORDS SYSTEM AND FACILITIES}

\section{F.4.1 Record Identification and Entry}

The Administrative Secretary shall maintain the project QA records and files. This individual, with the assistance of the QA Coordinator, shall identify items to be included as part of the project records. All members of the core peer review group shall be required to obtain a determination as to whether an item should be entered into the QA project records system from the Administrative Secretary or the QA Coordinator. When it is determined that an item should become part of the project records, the Administrative Secretary shall assign that item a unique identification number, enter that number and item description into the appropriate document $\log$ or index, make a duplicate file copy, and place the original item and copy into the appropriate file/storage location.

Each document shall be legible, with all requested information provided (use N/A if not applicable); adequately identifiable to the item or activity involved; and stamped, initialed, or signed, and dated. The record shall be in black or blue-black ink or typed.

\section{F.4.2 Records Organization}

As noted in Sec. F.1, two types of records shall be maintained for the project: those documenting peer review activities and those related to QA activities. These two types of documents are generally filed separately, using parallel organizational schemes. 


\title{
QUALITY ASSURANCE PROGRAM \\ ARGONNE PEER REVIEW ACTIVITIES FOR THE SALT HOST-ROCE PORTION OP THE CIVILIAN RADIOACTIVE WASTE MANAGEMENT PROGRAM
}

\author{
APPENDIX F: QAP-5, QA Records Procedures
}

Project No.: 23562

Page: 12 of 15

Issued: $8 / 12 / 86$

Revision: 0

\section{F.4.2.1 Records of Review Activities}

As described in Sec. F.3, all records of review activities shall be considered as either incoming or outgoing. Generally speaking, incoming records are those documents or items providing information and input to the review process; outgoing records are those documents or items requesting input to the review process or those providing information on the results of a particular review activity.

All incoming records shall be categorized according to source and assigned a code as follows: all incoming items from DOE shall be assigned the code ASDI, and all items from non-DOE sources shall be assigned the code ASI. Similarly, all QA records consisting of items outgoing to DOE shall be categorized as ASDO, and those items sent to non-DOE entities shall be classified as ASO. Individual documents within each of these four categories (i.e., ASDI, ASI, ASDO, and ASO) shall be assigned numbers sequentially, as they are entered into the records system, and the code and number shall be recorded on the document. Thus, individual items in category ASDI, for example, are identified by the codes ASDI-1, ASDI-2, ASDI-3, and so on. Each item shall also be marked with a location number indicating the section of the storage files where it will be placed.

A $\log$ of documents or records shall be maintained for each of the above four categories. For each document or record in that category, the log shall contain the individual QA record identification number (code plus number), the name(s) of the individual(s) originating the item and the recipient(s), the date the item was sent (outgoing) or received (incoming) by ANL, and a brief description of the subject matter of the item. Each log shall be updated daily, as required, as new items are entered into the records system. As each $\log$ is updated, the last page shall be replaced by the updated page. Each complete log shall be maintained on word-processing equipment; as each update occurs, the latest version shall be stored on floppy disks. A back-up disk shall be maintained for each disk, and all disks shall be kept in an insulated and locked fire-resistant safe when not in use by the Administrative Secretary. 


\title{
QUALITY ASSURANCE PROGRAM \\ ARGONNE PEER REVIEW ACTIVITIES FOR THE SALT HOST-ROCK PORTION OF THE CIVIILAN RADIOACTIVE WASTE MANAGEMENT PROGRAM
}

\author{
APPENDIX F: QAP-5, QA Records Procedures
}
Project No.: 23562
Page: 13 of 15
Issued: $8 / 12 / 86$
Revision: 0

A peer review documentation index shall also be maintained to expedite retrieval of documents or records pertaining to a particular review activity. This index shall be a standard form for entering information identifying the document or material reviewed, the contractor, the Review Session Chairman, and the on-site and off-site panelists involved in the review. Space shall also be provided to enter the QA code and number (e.g., ASDO-1 and ASI-5) for all documentation (Fig. F.2), as well as any preliminary preparation performed prior to receipt of the document for review from SRPO. As new records or documentation of specific steps in the review process is entered into the records system, the numbers shall be added to the appropriate space on the index maintained for that particular review. An index shall be filled out for each review, and all indexes shall become part of the QA records after each review is completed.

\section{F.4.2.2 Records of QA Activities}

An organizational system shall be established for recording QA activities; the system shall be parallel to that in place for organizing and handling records of peer review activities. All QA records shall be considered either incoming or outgoing, and each of these groups shall be further divided into DOE and non-DOE categories. Codes for QA records analogous to those for review activities (i.e., QASDI, QASI, QASDO, and QASO) and individual items in each category shall be assigned sequential numbers as they are entered into the records system. Thus, individual items in category QASDI, for example, are identified by the numbers QASDI-1, QASDI-2, QASDI-3, and so on. All numbers shall be recorded on the document, and each item shall also be marked with a category number that indicates the portion of the QA Program to which the record pertains. Categories 1-18 shall correspond to the 18 sections of the QA Plan and the 18 basic requirements of ANSI/ASME NQA-1. Category 19 shall be for miscellaneous QA records, and category 20 shall be for records pertaining to the project deliverable data and reporting requirements. 
ARGONNE PEER REVIEW ACTIVITIES FOR THE SALT HOST-ROCK PORTION

OF THE CIVILIAN RADIOACTIVE WASTE MANAGEMENT PROGRAM

APPENDIX F: QAP-5, QA Records Procedures

Project No:: 23562

Page: 14 of 15

Issued: $8 / 12 / 86$

Revision: 0

A $\log$ of QA records shall be maintained in the files for each of the four categc ies (i.e., QASDI, QASI, QASDO, and QASO). Each log shall contain analogous information and shall be maintained in the same manner as described in Sec. F.4.2.1.

An index of QA records shall also be maintained. This index shall consist of a form for each of the 20 categories, with each category identified and with space for entering the code and number of the items as they are entered into the records system. This index facilitates the location and retrieval of $\mathrm{QA}$ records in the files.

\section{F.4.3 Storage Facilities}

All records for active projects maintained for QA purposes shall be stored in insulated, fire-resistant filing cabinets with locks. One set of cabinets shall be located in the work area of the Administrative Secretary, which is also the outer office of the Peer Review Panel Chairman. A second set of cabinets containing the duplicate set of QA records shall be located in a nonadjacent work area. The doors to these areas shall have locks to prevent unauthorized access. The rooms are equipped with an automatic sprinkler system and a heat sensor, both of which are part of the fire alarm system for the building. This system is part of a laboratorywide system that automatically and simultaneously activates an alarm in the building and at the ANL Fire Department, in the event of a fire.

\section{F.4.4 Access to Project Records}

Direct access to the files containing the project records maintained for QA purposes shall be limited to the Administrative Secretary, the Peer Review Panel Chairman, and the QA Coordinator. The Administrative Secretary shall provide copies of records to individuals for examination. If a copy of a record is to be removed from the file for more than a short period of time, a marker shall be placed in that file location, with the name of the individual taking the document and the date. When returned, the Administrative Secretary shall remove the marker and replace the record copy in its 


\section{QUALITY ASSURANCE PROGRAM \\ ARGONNE PEER REVIEW ACTIVITIES FOR THE SALT HOST-ROCK PORTION OF THE CIVILIAN RADIOACTIVE WASTE MANAGEMENT PROGRAM}

APPENDIX F: QAP-5, QA Records Procedures

Project No.: 23562

Page: 15 of 15

Issued: $8 / 12 / 86$

Revision: 0

proper location. In most cases, copies of QA records, not the originals, shall be removed from the Administrative Secretary's work area.

\section{F.4.5 Records Turnover}

As noted in Sec. F.4.1, dual copies of all QA records shall be maintained. The original of each record shall be transmitted to SRPO for processing and storage during records turnover. These records shall be submitted annually to SRPO as a records turnover package in accordance with instructions to be provided ANL by SRPO.

\section{F.4.6 Records Retention}

Following records turnover, the ANL copies of the records submitted to SRPO shall be moved to an interim storage location. This location shall also provide controlled access to the records and shall be serviced by the building and sitewide fire alarm and sprinkler systems. Storage shall be maintained in fire-resistant cabinets with locks. These records shall be retained in this location for a period of three years following records turnover. At the end of this period, the records shall be transferred to a secure, dead-storage area for retention in locked, fire-resistant cabinets. Dead storage shall be maintained for another two years, after which time the records may be destroyed. 
QUALITY ASSURANCE PROGRAM

ARGONNE PEER REVIEW ACTIVTIES FOR THE SALT HOST-ROCK PORTION OF THE CIVILIAN RADIOACTIVE WASTE MANAGEMENT PROGRAM

APPENDIX G

Deliverable Data and Reporting Requirements 


\section{QUALITY ASSURANCE PROGRAM \\ ARGONNE PEER REVIEW ACTIVTIES FOR THE SALT HOST-ROCK PORTION \\ OF THE CIVILIAN RADIOACTIVE WASTE MANAGEMENT PROGRAM}

APPENDIX G: Deliverable Data and Reporting Requirements
Project No.: 23562

Page: 1 of 5

Issued: $8 / 12 / 86$

Revision: 0

\section{G.1 GENERAL}

Appendix $G$ describes the $Q A$ deliverable data and reporting requirements stipulated by SRPO for ANL-conducted multidisciplinary peer reviews of DOE-contractor documents associated with the salt host-rock portion of the CRWM program.

\section{G.2 QA REQUIREMENTS}

ANL shall furnish all QA deliverables identified in the SRPO QA specification. These deliverables are described in Secs. G.2.1-G.2.6 and listed in Table G.1.

\section{G.2.1 Monthly Summary}

ANL shall submit a monthly summary of QA-related activities. This summary shall be included in the DOE monthly project management report and shall include, as appropriate, the following information:

- Changes in organizational structure, project responsibilities, QA matters, or lead technical/scientific personnel.

- Changes in the QA Plan or implementing procedures.

- Changes in review, test, audit, or surveillance schedules.

- Results of ANL-implemented QA inspections.

- Status of corrective actions occurring as a result of inspections, nonconformance dispositions, and reported unusual occurrences.

Copies of audit, surveillance, and nonconformance reports shall be included in the monthly summary. 
APPENDIX G: Deliverable Data and Reporting Requirements
Project No.: 23562

Page: 2 of 5

Issued: $8 / 12 / 86$

Revision: 0

TABLE G.1 Summary of Deliverable Data and Reporting Requirements for ANL's Peer Review Activities

\begin{tabular}{|c|c|c|c|c|}
\hline Title & Frequency & $\begin{array}{l}\text { As of } \\
\text { Date }\end{array}$ & $\begin{array}{c}\text { When } \\
\text { to Be } \\
\text { Submitted }\end{array}$ & $\begin{array}{c}\text { SRPO } \\
\text { Distribution }\end{array}$ \\
\hline $\begin{array}{l}\text { Monthly summaries } \\
\text { (Sec. G.2.1) }\end{array}$ & Monthly & $\begin{array}{l}\text { End of } \\
\text { prior } \\
\text { month }\end{array}$ & $\begin{array}{l}\text { Within two } \\
\text { weeks of } \\
\text { prior month }\end{array}$ & $\begin{array}{l}\text { Project Manager, } \\
\text { QA Manager }\end{array}$ \\
\hline $\begin{array}{l}\text { Unusual occur- } \\
\text { rence reports } \\
\text { (Sec. G.2.2) }\end{array}$ & $\begin{array}{l}\text { On each } \\
\text { occurrence }\end{array}$ & $\begin{array}{l}\text { At time } \\
\text { of oc- } \\
\text { currence; } \\
\text { verbal } \\
\text { within } \\
48 \text { hours }\end{array}$ & $\begin{array}{l}\text { In writing, } \\
\text { within } 14 \\
\text { days of } \\
\text { occurrence }\end{array}$ & $\begin{array}{l}\text { Project Manager, } \\
\text { QA Manager }\end{array}$ \\
\hline $\begin{array}{l}\text { QA Program } \\
(\text { Sec. G.2.3) }\end{array}$ & $\begin{array}{l}\text { One time } \\
\text { and with } \\
\text { each } \\
\text { revision }\end{array}$ & & $\begin{array}{l}\text { Within } 21 \\
\text { days of } \\
\text { revision }\end{array}$ & $\begin{array}{l}\text { Project Manager, } \\
\text { QA Manager }\end{array}$ \\
\hline $\begin{array}{l}\text { QA Plan } \\
\text { (Sec.G.2.3) }\end{array}$ & $\begin{array}{l}\text { One time } \\
\text { and with } \\
\text { each } \\
\text { revision a }\end{array}$ & & $\begin{array}{l}\text { Within } 21 \\
\text { days of } \\
\text { revision }\end{array}$ & $\begin{array}{l}\text { Project Manager, } \\
\text { QA Manager }\end{array}$ \\
\hline $\begin{array}{l}\text { QA procedures } \\
\text { (Sec. G.2.3) }\end{array}$ & $\begin{array}{l}\text { One time } \\
\text { and with } \\
\text { each } \\
\text { revision a }\end{array}$ & & $\begin{array}{l}\text { Within } 21 \\
\text { days of } \\
\text { revision }\end{array}$ & $\begin{array}{l}\text { Project Manager, } \\
\text { QA Manager }\end{array}$ \\
\hline $\begin{array}{l}\text { Nonconformance } \\
\text { reports (Sec. } \\
\text { G.2.4) }\end{array}$ & Monthly & & $\begin{array}{l}\text { With monthly } \\
\text { status report }\end{array}$ & $\begin{array}{l}\text { Project Manager, } \\
\text { QA Manager }\end{array}$ \\
\hline
\end{tabular}




\section{ARGONNE PEER REVIEW ACTIVTIES FOR THE SALT HOST-ROCE PORTION} OF THE CIVILIAN RADIOACTIVE WASTE MANAGEMENT PROGRAM

APPENDIX G: Deliverable Data and Reporting Requirements
Project No.: 23562

Page: 3 of 5

Issued: $8 / 12 / 86$

Revision: 0

TABLE G.1 (Cont'd)

$\begin{array}{llll} & & \text { When } & \text { SRPO } \\ \text { Title } & \text { Fs of } & \text { to Be } & \text { Distribution }\end{array}$

\begin{tabular}{|c|c|c|c|}
\hline $\begin{array}{l}\text { Project records } \\
\text { list (Sec. } \\
\text { G.2.5) }\end{array}$ & $\begin{array}{l}\text { One time } \\
\text { and with } \\
\text { eacis } \\
\text { revision a }\end{array}$ & $\begin{array}{l}\text { Within } 21 \\
\text { days of } \\
\text { revision }\end{array}$ & $\begin{array}{l}\text { Project Manager, } \\
\text { QA Manager }\end{array}$ \\
\hline $\begin{array}{l}\text { Records turnover } \\
\text { (Sec. G.2.6) }\end{array}$ & $\begin{array}{l}\text { Yearly or } \\
\text { upon } \\
\text { contract } \\
\text { revision }\end{array}$ & $\begin{array}{l}\text { Within } 90 \\
\text { days of } \\
\text { notification } \\
\text { from SRPO }\end{array}$ & Project Manager \\
\hline
\end{tabular}

${ }^{a}$ Revisions shall be handled according to document control procedures (App. C).

\section{G.2.2 Unusual Occurrence Report}

ANL shall immediately report to SRPO if the QA Program cannot be established, implemented, or maintained. ANL shall also immediately report any deviations from the planned or expected course of an activity or operation that have or could have significant programmatic (i.e., reliability, cost, or schedule), safety, health, or environmental impact.

The SRPO Project Manager and the SRPO QA Manger shall be verbally notified of problems within 48 hours. No later than 14 calendar days from initial notification, ANL shall provide written notification which, based on available information, shall include the following:

- The name of the organization and the location where the unusual occurrence took place. 


\section{QUALITY ASSURANCE PROGRAM \\ ARGONNE PEER REVIEW ACTIVITIES FOR THE SALT HOST-ROCK PORTION \\ OF THE CIVILIAN RADIOACTIVE WASTE MANAGEMENT PROGRAM}

APPENDIX G: Deliverable Data and Reporting Requirements
Project No.: 23562

Page: 4 of 5

Issued: $8 / 12 / 86$

Revision: 0

- When, how, and why the unusual occurrence took place.

- What caused the unusual occurrence and the immediate effects of the incident.

- What corrective action is recommended or has been taken.

Following SRPO's evaluation of an unusual occurrence report, ANL shall be notified in writing if further corrective action is required, or if the problem is closed and no further action is required.

\section{G.2.3 QA Program}

Controlled copies of the ANL QA Program shall be submitted to SRPO for acceptance before use and after revision.

\section{G.2.4 Nonconformance Reports}

ANL shall evaluate all nonconformances for reporting as potential unusual occurrences. Copies of all nonconformance reports shall be transmitted to SRPO with the appropriate monthly summary reports (Sec. G.2.1) for review and concurrence.

\section{G.2.5 Project Records List}

A subject-oriented project records list indicating those types of records planned to be maintained in the project QA files shall be prepared and submitted to the SRPO Project Manager and QA Manager for review and acceptance. The project records list shall be updated periodically as work progresses. Revised project records lists shall be submitted to SRPO for acceptance and shall be handled according to project document control procedures (App. C). 


\section{QUALITY ASSURANCE PROGRAM \\ ARGONNE PEER REVIEW ACTIVITIES FOR THE SALT HOST-ROCK PORTION OF THE CIVILIAN RADIOACTIVE WASTE MANAGEMENT PROGRAM}

APPENDIX G: Deliverable Data and Reporting Requirements
Project No.: 23562

Page: 5 of 5

Issued: $8 / 12 / 86$

Revision: 0

\section{G.2.6 Records Turnover}

Records shall be submitted annually to SRPO as a records turnover package. Requirements for collecting and packaging items for records turnover, along with the forms to be completed by ANL, shall be transmitted by letter from SRPO.

\section{G.3 REFERENCE}

Quality Assurance Specification for Argonne National Laboratory: Multidisciplinary Peer Reviews of DOE-Contractor Documents for Salt Host-Rock Portion of CRWM Program, U.S. Department of Energy, Salt Repository Project Office, Columbus, Ohio, unpublished document (Sept. 11, 1985). 